\title{
51. MAJOR- AND TRACE-ELEMENT CHEMISTRY OF HOLE 504B BASALTS AND THEIR ALTERATION PRODUCTS (COSTA RICA RIFT, DEEP SEA DRILLING PROJECT LEG 70) ${ }^{1}$
}

\author{
A. Ya. Sharaskin, A. A. Migdisov, I. A. Rostschina, and A. Z. Miklishansky, \\ V. I. Vernadsky Institute of Geochemistry and Analytical Chemistry, \\ U.S.S.R. Academy of Sciences, Moscow, U.S.S.R.
}

\begin{abstract}
Major and trace element compositions of basalts from the lower part of Hole 504B indicate their cogenetic nature. The cored sequence of interlayered pillow lavas and massive lava flows was produced by eruption of lavas, slightly variable in composition. Plagioclase and olivine crystallization in a shallow magma chamber, followed by small-scale fractionation at higher levels, is responsible for these variations. Except in highly fractured zones within the basement, there are systematic variations in the style and degree of rock alteration with depth. Trace element characteristics of altered rocks and secondary minerals indicate that progressive changes in sea water composition occurred as it reacted with basaltic crust.
\end{abstract}

\section{INTRODUCTION}

The re-entry and drilling operations at Hole 504B eventually resulted in one of the deepest penetrations into the basaltic basement of any spreading center. Obviously, such deep penetration into the basement provides important information on the origin of the oceanic crust, and the recovered samples, from the 561-m-thick basement section, certainly are worthy of comprehensive study.

The aim of this paper is to present geochemical data on rocks from the lower part of Hole 504B, cored during Leg 70, representing a certain stage of magmatic activity at the Costa Rica Rift. In addition, some veinforming minerals and rock alteration zones have been studied to elucidate patterns of redistribution of elements by secondary processes. Finally, one sample apiece from Holes 507B and 510, on the Galapagos Rift, also drilled during Leg 70 , were analyzed for comparison with the samples from Hole 504B. Locations for all these holes are shown on Figure 1.

\section{ANALYTICAL METHODS}

Studied core samples and separated mineral fractions were analyzed using wet chemical (major elements, $\mathrm{FeO}, \mathrm{H}_{2} \mathrm{O}^{+}$), XRF (major elements, $\mathrm{Cr}, \mathrm{V})$, flame-photometry $(\mathrm{K}, \mathrm{Na}, \mathrm{Li})$, and neutron-activation (REE, and other trace elements) methods. Prior to neutron-activation during the mineral analysis the REE were concentrated by the radiochemical method. All these methods are described in detail by Migdisov et al. (1979, 1980). E. V. Bezrogova and I. A. Rostschina assisted in the chemical and XRF analyses, and A. Z. Miklishansky and A. A. Migdisov performed the neutron-activation determinations.

We used a series of standard rock samples (Flanagan, 1973) and interlaboratory standards for the materials from Holes 510 and 504B to check the accuracy of the analytical results. The obtained data are given in Tables 1 and 2. As one can see, there is a systematic disagreement between the chemical and XRF data for $\mathrm{Al}_{2} \mathrm{O}_{3}$ and $\mathrm{MgO}$. The XRF data for these components are in a good agreement with

\footnotetext{
${ }^{1}$ Cann, J. R., Langseth, M. G., Honnorez, J., Von Herzen, R. P., White, S. M., et al. Init. Repts. DSDP, 69: Washington (U.S. Govt. Printing Office).
}

data obtained in other laboratories on the same samples $(\mathrm{H}$. W. Hubberten, pers. comm.); hence, they were chosen as the correct results.

The corrected analytical data for studied materials are listed in Tables 3,4 , and 5 .

\section{BASALT PETROLOGY}

The shipboard scientific party defined 26 lithologic units for the 347-meter basement section cored in the Hole 504B during Leg 70. The upper part of basement, 214 meters thick, was drilled during Leg 69. Being different in geological features, these units include only five petrographic types of basalts, distinguished according to their phenocryst assemblages. The phenocrysts are absent in aphyric types (A-type) and may consist of two, three, or four mineral phases in phyric rocks: olivine + plagioclase (OP-type), plagioclase + clinopyroxene (PC-type), olivine + plagioclase + clinopyroxene (OPCtype), and olivine + plagioclase + clinopyroxene + spinel (SV-type). Similar rock types were recognized in the upper part of the hole (Site 501/504 report, this volume).

A number of previous investigators postulated that compositional variations among ocean-floor tholeiites (OFT) are caused either by fractional crystallization in a shallow magma chamber, or by primary differences in the mantle-derived melts. The resultant rocks in each case differ in certain geochemical peculiarities, which can be used therefore as petrogenetic criteria.

The obtained geochemical data for the Hole 504B samples, as well as for two samples from the Galapagos Rift (one 0.6 m.y. old, Hole 507B; another 2.4 m.y. old, Hole 510) are listed in Tables 3 and 4. We used the $\mathrm{MgO} / \mathrm{CaO}$ versus $\mathrm{Al}_{2} \mathrm{O}_{3} / \mathrm{FeO}^{*}$ correlation diagram (Fig. 2) to test the possible regularities in the bulk-rock compositional variations. This diagram is fairly useful in interpreting graphically the character of OFT magma evolution, because the correlation trends, controlled by a single phase, namely olivine, plagioclase, or clinopyroxene fractionation from a given melt composition, will be oriented on the diagram in three sharply different direc- 


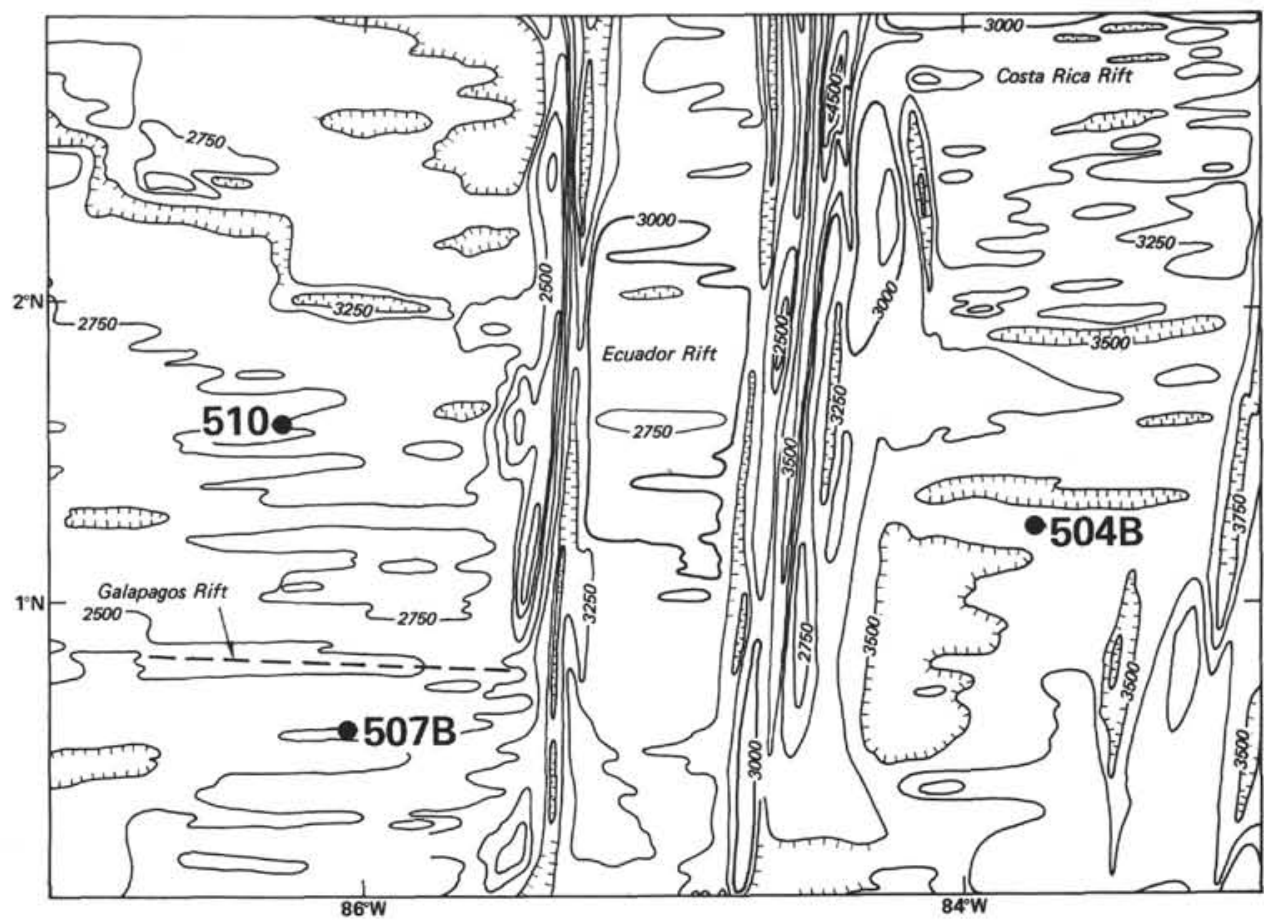

Figure 1. Location of Holes 504B, 507B, and 510, drilled during DSDP Legs 69 and 70.

Table 1. Major-element distribution (wt.\%) in Leg 70 interlaboratory reference samples (see Appendix, this volume).

\begin{tabular}{|c|c|c|c|c|c|c|c|c|}
\hline \multirow[b]{2}{*}{ Component } & \multicolumn{2}{|c|}{$70-1 \mathrm{C}-1 \mathrm{~A}$} & \multicolumn{2}{|c|}{$70-1 \mathrm{C}-1 \mathrm{~B}$} & \multicolumn{2}{|c|}{$70-1 \mathrm{C}-2 \mathrm{~A}$} & \multicolumn{2}{|c|}{$70-1 C-3 A$} \\
\hline & $\begin{array}{c}\text { Wet } \\
\text { Chemical }\end{array}$ & XRF & $\begin{array}{c}\text { Wet } \\
\text { Chemical }\end{array}$ & XRF & $\begin{array}{c}\text { Wet } \\
\text { Chemical }\end{array}$ & XRF & $\begin{array}{c}\text { Wet } \\
\text { Chemical }\end{array}$ & XRF \\
\hline $\mathrm{SiO}_{2}$ & 50.1 & 50.6 & 50.5 & 50.2 & 50.2 & 50.6 & 49.5 & 49.8 \\
\hline $\mathrm{TiO}_{2}^{2}$ & 0.82 & 0.84 & 0.82 & 0.84 & 0.99 & 1.00 & 0.87 & 0.85 \\
\hline $\mathrm{Al}_{2} \mathrm{O}_{3}$ & 16.80 & 15.95 & 16.65 & 15.81 & 15.90 & 15.55 & 17.50 & 16.72 \\
\hline $\mathrm{Fe}_{2} \mathrm{O}_{3}$ & $2.46\}$ & 8.96 & $\left\{\begin{array}{l}2.00 \\
7\end{array}\right.$ & 8.84 & $\left\{\begin{array}{l}2.62 \\
7\end{array}\right\}$ & 9.63 & $\left\{\begin{array}{l}2.16 \\
6.79\end{array}\right\}$ & 8.57 \\
\hline $\begin{array}{l}\mathrm{FeO} \\
\mathrm{MnO}\end{array}$ & $\begin{array}{l}6.941 \\
0.148\end{array}$ & 0.159 & $\begin{array}{r}7.38 \mid \\
0.121\end{array}$ & 0.153 & $\begin{array}{r}|7.34| \\
0.119\end{array}$ & 0.167 & $\begin{array}{r}6.79\} \\
0.111\end{array}$ & 0.148 \\
\hline $\mathrm{MgO}$ & 7.62 & 8.20 & 7.60 & 8.04 & 7.70 & 8.26 & 8.00 & 8.51 \\
\hline $\mathrm{CaO}$ & 13.00 & 13.49 & 12.92 & 13.29 & 12.33 & 12.55 & 12.33 & 12.90 \\
\hline $\mathrm{Na}_{2} \mathrm{O}$ & 1.65 & - & 1.72 & - & 2.01 & - & 1.89 & - \\
\hline $\mathrm{K}_{2} \mathrm{O}$ & 0.024 & 0.06 & 0.025 & 0.05 & 0.02 & 0.06 & 0.02 & 0.04 \\
\hline $\mathrm{P}_{2} \mathrm{O}_{5}$ & 0.050 & 0.069 & 0.045 & 0.070 & 0.065 & 0.092 & 0.065 & 0.071 \\
\hline $\mathrm{H}_{2} \mathrm{O}^{+}$ & 0.70 & - & 0.60 & - & 0.76 & - & 0.71 & - \\
\hline$\Sigma$ & 100.31 & & 100.37 & & 100.05 & & 99.94 & \\
\hline
\end{tabular}

tions. In theory, if one of these phases has a fixed composition, points on the diagram for the original magma together with evolved and cumulate rocks, originating by fractionation of this phase will plot along a straight line. In practice, there are small compositional variations in phenocryst phases of cogenetic OFT rock series, as illustrated in Figure 2 by two concrete examples of plagioclase- and olivine-phyric rock suites from the FAMOUS area. The sharp difference between the singlemineral fractionation trends make the diagram very sensitive to any change in proportions of the crystalline phases which separated from OFT magmas during their cooling history.

The correlation between $\mathrm{MgO} / \mathrm{CaO}$ and $\mathrm{Al}_{2} \mathrm{O}_{3} / \mathrm{FeO}^{*}$ ratios in Hole 504B rocks is shown on Figure 3A. There

Table 2. Minor- and rare-earth-element distribution in Leg 70 interlaboratory reference samples, and $\mathrm{W}-\mathrm{I}$ and $\mathrm{BM}$ reference samples.

\begin{tabular}{|c|c|c|c|c|c|c|c|c|c|c|c|c|c|}
\hline & \multicolumn{3}{|c|}{$70-1 \mathrm{C}-1 \mathrm{~A}$} & \multicolumn{2}{|c|}{$70-I C-1 B$} & \multicolumn{2}{|c|}{$70-1 C-2 A$} & \multicolumn{2}{|c|}{$70-I C-3 A$} & \multicolumn{2}{|c|}{$W-1$} & \multicolumn{2}{|c|}{ BM } \\
\hline & $\mathrm{XRF}_{\mathrm{X}}^{\mathrm{AA}}$ & INAA & RNAA & ${ }_{\mathrm{XRF}}^{\mathrm{AA}}$ & INAA & $\begin{array}{c}\text { AA, } \\
\text { XRF }\end{array}$ & INAA & $\underset{X R F^{\mathrm{a}}}{\mathrm{AA}}$ & INAA & $1^{a}$ & $2^{b}$ & $1^{a}$ & $2^{\mathrm{b}}$ \\
\hline $\mathrm{Li}$ & 5 & - & - & 5.5 & - & 6 & - & 7 & - & - & - & 75 & 70 \\
\hline Sr & 56 & - & - & 48 & - & 123 & - & 100 & - & - & - & 237 & 230 \\
\hline $\mathrm{Ni}$ & 75 & - & - & 72 & - & 83 & - & 114 & - & - & - & 54 & 57 \\
\hline Co & - & 44 & - & - & 40 & - & 39 & - & 36 & 46.3 & 47 & 38 & 34 \\
\hline $\mathrm{Cu}$ & 100 & - & - & 101 & - & 87 & - & 217 & - & - & - & 44 & 45 \\
\hline $\mathrm{Zn}$ & 67 & - & - & 66 & - & 79 & - & 72 & - & - & - & 121 & 107 \\
\hline $\mathrm{v}$ & $260^{\mathrm{a}}$ & - & - & $230^{a}$ & - & $340^{\mathrm{a}}$ & - & $210^{\mathrm{a}}$ & - & - & - & 200 & 180 \\
\hline $\mathrm{Cr}$ & $400^{\mathrm{a}}$ & 438 & - & $380^{\mathrm{a}}$ & 394 & $320^{\mathrm{a}}$ & 347 & $400^{\mathrm{a}}$ & 408 & 117 & 114 & 120 & 123 \\
\hline Sc & - & 44 & - & - & 42 & - & 46 & - & 42 & 37 & 35 & 31 & 34 \\
\hline La & - & 0.9 & 0.85 & - & 0.8 & - & 1.2 & - & 1.05 & 9.7 & 9.8 & 8.6 & 8.9 \\
\hline $\mathrm{Ce}$ & - & 6.6 & - & - & 4.7 & - & 6.6 & - & 7.8 & 24 & 23 & 23 & 23 \\
\hline $\mathrm{Sm}$ & - & 1.68 & 1.65 & - & 1.62 & - & 2.29 & - & 2.26 & 3.5 & 3.6 & 4.0 & 4.0 \\
\hline Eu & - & 0.69 & 0.66 & - & 0.68 & - & 0.97 & - & 0.97 & 1.12 & 1.11 & 1.15 & 1.1 \\
\hline $\mathrm{Tb}$ & - & 0.46 & 0.462 & - & - & - & 0.68 & - & 0.64 & 0.59 & 0.65 & 1.0 & 1.0 \\
\hline $\mathrm{Tm}$ & - & 0.37 & 0.365 & - & - & - & - & - & 0.43 & - & - & - & - \\
\hline $\mathrm{Yb}$ & - & 1.90 & 1.525 & - & 1.85 & - & 2.77 & - & 2.37 & 2.3 & 2.1 & 3.2 & 3.5 \\
\hline Lu & - & 0.376 & 0.383 & - & 0.32 & - & 0.49 & - & 0.33 & 0.39 & 0.35 & 0.37 & 0.4 \\
\hline $\mathrm{Hf}$ & - & 1.5 & - & - & 1.7 & - & 1.8 & - & 1.6 & 2.8 & 2.7 & 2.7 & 3.1 \\
\hline
\end{tabular}


Table 3. Distribution of major elements in Leg 70 basalts.

\begin{tabular}{|c|c|c|c|c|c|c|c|c|c|c|c|c|c|c|}
\hline $\begin{array}{c}\text { Sample } \\
\text { (interval in cm) }\end{array}$ & $\begin{array}{l}\text { Sample } \\
\text { No. }\end{array}$ & $\mathrm{SiO}_{2}$ & $\mathrm{TiO}_{2}$ & $\mathrm{Al}_{2} \mathrm{O}_{3}$ & $\mathrm{Fe}_{2} \mathrm{O}_{3}$ & $\mathrm{FeO}$ & $\mathrm{MnO}$ & $\mathrm{MgO}$ & $\mathrm{CaO}$ & $\mathrm{Na}_{2} \mathrm{O}$ & $\mathrm{K}_{2} \mathrm{O}$ & $\mathrm{P}_{2} \mathrm{O}_{5}$ & $\mathrm{H}_{2} \mathrm{O}^{+}$ & $\Sigma$ \\
\hline 507B-1-1, 32-36 & 23 & 50.2 & 1.95 & 13.55 & 2.23 & 11.36 & 0.23 & 7.37 & 9.69 & 2.48 & 0.118 & 0.138 & 0.14 & 99.46 \\
\hline $510-10-1,69-83$ & 1 & 50.35 & 0.83 & 15.88 & 2.20 & 7.06 & 0.14 & 8.12 & 12.96 & 1.68 & 0.03 & 0.059 & 0.65 & 99.97 \\
\hline $504 \mathrm{~B}-34-1,19-24$ & 220 & 49.4 & 0.96 & 15.80 & 3.33 & 5.64 & 0.16 & 9.45 & 11.55 & 2.16 & 0.148 & 0.076 & 0.97 & 99.65 \\
\hline $35-1,14-18$ & 282 & 46.8 & 0.83 & 17.20 & 3.84 & 4.92 & 0.19 & 7.99 & 12.55 & 2.23 & 0.126 & 0.034 & 2.41 & 99.12 \\
\hline $36-1,91-110$ & 11 & 50.4 & 1.00 & 15.55 & 2.62 & 7.34 & 0.14 & 8.26 & 12.99 & 2.01 & 0.04 & 0.078 & 0.76 & 100.53 \\
\hline $40-1,55-60$ & 510 & 47.6 & 0.82 & 15.80 & 2.74 & 5.95 & 0.16 & 11.23 & 12.2 & 1.86 & 0.073 & 0.050 & 2.03 & 100.47 \\
\hline $40-2,72-88$ & 111 & 49.65 & 0.86 & 17.11 & 2.16 & 6.79 & 0.13 & 8.51 & 12.33 & 1.89 & 0.03 & 0.068 & 0.71 & 100.24 \\
\hline $41-3,146-148$ & 628 & 49.8 & 0.94 & 16.65 & 2.24 & 6.85 & 0.15 & 8.09 & 12.84 & 2.20 & 0.065 & 0.058 & 0.57 & 100.46 \\
\hline $43-1,80-82$ & 680 & 49.3 & 0.92 & 15.65 & 3.90 & 5.94 & 0.16 & 8.41 & 12.78 & 2.24 & 0.077 & 0.050 & 0.47 & 99.98 \\
\hline $47-1,46-48$ & 808 & 50.2 & 1.04 & 14.80 & 3.02 & 7.32 & 0.17 & 8.86 & 12.35 & 2.16 & 0.065 & 0.064 & 0.25 & 100.38 \\
\hline $49-1,140-147$ & 933 & 50.0 & 0.88 & 16.30 & 2.16 & 7.19 & 0.17 & 8.14 & 13.03 & 2.16 & 0.096 & 9.054 & 0.55 & 100.73 \\
\hline $49-2,7-10$ & 936 & 49.0 & 0.88 & 15.45 & 4.21 & 6.16 & 0.14 & 9.54 & 10.68 & 1.94 & 0.201 & 0.046 & 1.98 & 100.23 \\
\hline $52-2,78-80$ & 1016 & 49.5 & 0.88 & 16.05 & 3.47 & 5.88 & 0.15 & 8.84 & 13.03 & 1.97 & 0.081 & 0.054 & 0.66 & 100.57 \\
\hline $64-2,32-35$ & 1424 & 50.0 & 1.23 & 14.05 & 4.18 & 7.22 & 0.20 & 8.63 & 12.04 & 2.25 & 0.078 & 0.080 & 0.42 & 100.38 \\
\hline $68-1,107-111$ & 1538 & 49.2 & 1.07 & 14.65 & 3.51 & 7.01 & 0.22 & 8.89 & 12.66 & 2.12 & 0.055 & 0.074 & 0.72 & 100.18 \\
\hline $69-1,14-17$ & 1540 & 49.7 & 1.18 & 14.60 & 3.93 & 6.62 & 0.24 & 8.62 & 12.16 & 2.24 & 0.058 & 0.074 & 0.61 & 100.04 \\
\hline $69-1,74-77$ & 1545 & 49.6 & 1.03 & 14.10 & 4.51 & 6.20 & 0.19 & 8.99 & 11.92 & 1.98 & 0.050 & 0.070 & 1.09 & 99.73 \\
\hline $70-1,79-82$ & 1556 & 49.6 & 0.91 & 14.65 & 4.87 & 4.62 & 0.13 & 9.52 & 11.11 & 2.33 & 0.096 & 0.54 & 1.71 & 99.60 \\
\hline $70-1,127-130$ & 1561 & 49.7 & 1.00 & 15.40 & 3.47 & 5.65 & 0.18 & 8.92 & 12.90 & 1.99 & 0.072 & 0.050 & 0.81 & 100.14 \\
\hline $70-2,20-23$ & 1564 & 49.8 & 0.99 & 15.40 & 3.57 & 5.34 & 0.18 & 8.87 & 12.97 & 2.14 & 0.070 & 0.050 & 0.72 & 101.1 \\
\hline
\end{tabular}

Table 4. Distribution of minor and rare-earth elements (ppm) in Leg 70 basalts.

\begin{tabular}{|c|c|c|c|c|c|c|c|c|c|c|c|c|c|c|c|c|c|c|c|c|c|c|c|c|}
\hline Hole & $\begin{array}{c}\text { Sample } \\
\text { No. }\end{array}$ & $\mathrm{Li}$ & Cs & Co & $\mathrm{Cr}$ & V & $\mathrm{Cu}$ & $\mathrm{Zn}$ & $\mathrm{Cd}$ & $\mathrm{Sb}$ & $\mathrm{Au}$ & $\mathrm{Ag}$ & $\mathrm{Sc}$ & $\mathrm{Ta}$ & $\mathrm{Hf}$ & $\mathrm{La}$ & $\mathrm{Ce}$ & $\mathrm{Nd}$ & $\mathrm{Sm}$ & Eu & $\mathrm{Tb}$ & $\mathrm{Tm}$ & $\mathrm{Yb}$ & Lu \\
\hline 507B & 23 & 6.3 & 2.2 & 38 & 77 & 440 & - & 59 & 0.12 & 1.0 & 0.086 & 0.061 & 45 & - & 2.5 & 2.8 & 12.3 & 10.2 & 4.37 & 1.262 & 1.079 & 0.676 & 3.748 & 0.590 \\
\hline 510 & 1 & 5 & - & 44 & 403 & 245 & 100 & 66 & - & 0.5 & - & - & 44 & - & 1.6 & 0.85 & 5.6 & - & 1.66 & 0.69 & 0.460 & 0.368 & 1.888 & 0.348 \\
\hline 504B & 220 & 10 & - & 32 & 317 & - & - & $4 \mathrm{I}$ & 0.11 & 0.6 & - & - & 34 & - & 1.3 & 2.15 & 6.9 & - & 1.88 & 0.850 & 0.395 & 0.300 & 1.318 & 0.253 \\
\hline $504 \mathrm{~B}$ & 282 & 8.9 & 1.7 & 42 & 332 & - & - & 53 & - & 0.9 & - & 0.099 & 38 & 0.30 & 1.6 & 1.24 & 8.0 & - & 2.32 & 1.061 & 0.584 & 0.358 & 1.826 & 0.318 \\
\hline $504 \mathrm{~B}$ & 11 & 7 & 1.2 & 39 & 347 & 340 & 87 & 79 & - & - & - & - & 46 & - & 1.8 & 1.20 & 6.6 & - & 2.29 & 0.970 & 0.680 & - & 2.770 & 0.490 \\
\hline $504 \mathrm{~B}$ & 510 & 17.5 & - & 34 & 366 & - & - & 69 & - & 1.2 & - & 0.049 & 43 & 0.21 & 2.0 & 1.72 & 8.1 & 5.8 & 1.97 & 0.965 & 0.591 & - & 2.324 & 0.282 \\
\hline $504 \mathrm{~B}$ & 111 & 7 & 1.1 & 36 & 408 & 210 & 217 & 72 & - & 2.2 & 0.039 & 0.102 & 42 & 0.46 & 1.6 & 1.05 & 7.8 & - & 2.26 & 0.972 & 0.636 & 0.428 & 2.370 & 0.329 \\
\hline $504 \mathrm{~B}$ & 628 & 3.6 & - & 36 & 282 & - & - & 58 & - & - & 0.156 & - & 39 & 2.1 & 1.1 & 2.0 & 10.0 & 8.1 & 3.165 & 1.424 & 0.813 & - & 2.643 & 0.264 \\
\hline $504 \mathrm{~B}$ & 808 & 5 & - & 38 & 161 & - & - & 88 & - & 2.0 & - & 0.009 & 43 & 1.1 & 1.5 & 1.6 & 11.0 & 8.4 & 2.960 & 1.105 & 0.673 & - & 2.479 & 0.350 \\
\hline $504 \mathrm{~B}$ & 933 & 5.3 & - & 43 & 335 & - & - & - & 2.05 & 1.9 & - & 0.122 & 42 & 2.4 & - & 1.6 & 7.8 & - & 2.43 & 1.1 & 0.784 & - & 2.966 & 0.424 \\
\hline 504B & 936 & 7.5 & - & 36 & 223 & - & - & 60 & 0.26 & 0.9 & - & 0.082 & 42 & 1.4 & 1.4 & 1.6 & 8.2 & - & 2.45 & 0.880 & 0.787 & 0.549 & 2.565 & 0.400 \\
\hline 504B & 1016 & 4.6 & - & 46 & 425 & - & - & 115 & 0.12 & 0.9 & 0.485 & 0.097 & 42 & 1.6 & 2.4 & 1.7 & 9.7 & 8.7 & & & 0.737 & 0.560 & 2.660 & 0.530 \\
\hline 504B & 1424 & 4.6 & 1.4 & 41 & 304 & - & - & 48 & - & 1.8 & - & - & 46 & 1.9 & 2.1 & 1. & 7.61 & - & 2.917 & 1.021 & 0.779 & 0.446 & 3.360 & 0.619 \\
\hline 504B & 1538 & 2.5 & 1.9 & 46 & 263 & - & - & 151 & 0.36 & 2.0 & 0.037 & - & 48 & 1.2 & 2.0 & 1.4 & 8.4 & - & 2.560 & 1.119 & 0.675 & 0.538 & 3.317 & 0.539 \\
\hline 504B & 1540 & 2.7 & - & so & 200 & - & - & 110 & - & - & - & - & 45 & 2.1 & 1.8 & 1.8 & 8.0 & 5.9 & 2.220 & 0.900 & 0.510 & 0.417 & 2.470 & 0.372 \\
\hline 504B & 1545 & 2.5 & - & 49 & 254 & - & - & 114 & 0.29 & - & - & - & 44 & 1.8 & - & 1. & 6. & - & 2.780 & & 0.7 & 0.499 & 2.496 & 0.543 \\
\hline 504B & 1556 & 3.4 & 1.4 & 35 & 343 & - & - & 81 & 2.0 & 1.6 & - & 0.058 & 42 & i. & 2.5 & 0.9 & 7.7 & 7.9 & 2.94 & 1.110 & 0.673 & 0.525 & 2.861 & 0.552 \\
\hline 504B & 1561 & 3.8 & 1.9 & 34 & 295 & - & - & 25 & 1.7 & - & - & - & 30 & 0.7 & 1.4 & 1.0 & 8.0 & 6.2 & 2.200 & 0.852 & 0.586 & 0.380 & 1.628 & 0.362 \\
\hline 504B & 1564 & - & - & 34 & 262 & - & - & 60 & 0.22 & - & - & - & 27 & 2.4 & 1.5 & 1.3 & 7.8 & - & 2.170 & 0.998 & 0.609 & 0.420 & 2.625 & 0.345 \\
\hline
\end{tabular}

is a main trend on the diagram, relating these rocks with the typical Fe-Ti-basalt from the Galapagos spreading center (the Hole 507B sample). This trend suggests that the rocks belong to a single magmatic series, the $\mathrm{Fe}-\mathrm{Ti}-$ basalts being the most-evolved rocks of the series. The greater variations in the $\mathrm{Al}_{2} \mathrm{O}_{3} / \mathrm{FeO}^{*}$ ratio than in the $\mathrm{MgO} / \mathrm{CaO}$ ratio indicate that plagioclase fractionation was the dominant factor of the magmatic evolution of these rocks. According to petrographic observations, plagioclase indeed is the most abundant phenocryst in the Hole 504B basalts.

The other important phenocryst phase is olivine. Those rocks relatively rich in this mineral, deviate on the diagram from the main trend in such a manner that, relative to their counterparts from the same lithologic unit, they have higher $\mathrm{MgO} / \mathrm{CaO}$ and somewhat lower $\mathrm{Al}_{2} \mathrm{O}_{3} / \mathrm{FeO}^{*}$ ratios. This is indicated by the shaded arrows in Figure 3A. In two cases, these olivine-enriched rocks belong to massive-flow sequences (Lithologic Units 27 and 46), and probably present within-flow olivine fractionation, superimposed on the main differentiation trend in a magma chamber. Similar relations between rock types of some pillow-lava sequences (Lithologic Units 23 and 30) indicate that small-scale olivine accumulation may also occur during the lava's ascent from the magma chamber to the surface.

Figure $3 \mathrm{~A}$ does not indicate significant clinopyroxene fractionation or accumulation in the Hole 504B samples. This is in good agreement with petrographic observations, suggesting that clinopyroxene crystallization occurs only at late stages of the cooling history of the lavas.

The inferred genetic relations between the various types of basalt from Hole 504B may be checked by means of trace-element-distribution patterns. If we consider, for example, the correlation of such elements as $\mathrm{Ti}$ and $\mathrm{Cr}$ along the differentiation trend, taking the $\mathrm{Al}_{2} \mathrm{O}_{3} / \mathrm{FeO}^{*}$ ratio as an indicator, we find a regular $\mathrm{Ti}$ enrichment and $\mathrm{Cr}$ depletion in the more-evolved rocks relative to the more primitive ones, exactly as one should expect for cogenetic series (Figs. 3B and 3C). The other trace elements, which are the least mobile in the course 
Table 5. Major and minor elements in altered basalt and smectites from Hole 504B, Leg 70.

\begin{tabular}{|c|c|c|c|c|c|c|c|c|c|c|c|}
\hline Component & $\begin{array}{c}504 \mathrm{~B}-34-1 \text {, } \\
47-50 \mathrm{~cm} \\
\text { No. } 224\end{array}$ & $\begin{array}{c}504 \mathrm{~B}-35-1 \text {, } \\
14-18 \mathrm{~cm} \\
\text { No. } 282\end{array}$ & $\begin{array}{c}504 \mathrm{~B}-37-3 \text {, } \\
70-75 \mathrm{~cm} \\
\text { No. } 401-1\end{array}$ & $\begin{array}{c}504 \mathrm{~B}-40-1 \text {, } \\
55-60 \mathrm{~cm} \\
\text { No. } 510\end{array}$ & $\begin{array}{c}504 \mathrm{~B}-40-1 \text {, } \\
90-95 \mathrm{~cm} \\
\text { No. } 517\end{array}$ & $\begin{array}{c}504 \mathrm{~B}-46-1 \text {, } \\
100-105 \mathrm{~cm} \\
\text { No. } 777\end{array}$ & $\begin{array}{c}504 \mathrm{~B}-46-1, \\
100-105 \mathrm{~cm} \\
\text { No. } 779\end{array}$ & $\begin{array}{l}504 \mathrm{~B}-52-1, \\
82-87 \mathrm{~cm} \\
\text { No. } 1000\end{array}$ & $\begin{array}{c}504 \mathrm{~B}-56-2, \\
98-103 \mathrm{~cm} \\
\text { No. } 1122\end{array}$ & $\begin{array}{l}\text { 504B-57-3, } \\
31-43 \mathrm{~cm} \\
\text { No. } 1164\end{array}$ & $\begin{array}{c}504 \mathrm{~B}-61-2, \\
67-70 \mathrm{~cm} \\
\text { No. } 1304\end{array}$ \\
\hline $\mathrm{SiO}_{2}(w \mathrm{t} . \%)$ & 44.0 & - & 43.6 & - & 38.8 & 47.5 & 45.8 & 47.2 & 45.7 & 48.4 & 42.7 \\
\hline $\mathrm{TiO}_{2}$ & 0.71 & - & 0.16 & - & 0.22 & 0.98 & 0.39 & 0.81 & 0.25 & 1.04 & 1.08 \\
\hline $\mathrm{Al}_{2} \mathrm{O}_{3}$ & 11.78 & - & 7.54 & - & 8.05 & 11.98 & 8.18 & 14.08 & 6.38 & 12.69 & 12.24 \\
\hline $\mathrm{Fe}_{2} \mathrm{O}_{3}$ & $5.31\}$ & 8.84 & $3.93\}$ & 8.24 & 4.14 & 6.80 & $9.09\}$ & 1131 & $\{13.71$ & 6.68 & 10.20 \\
\hline $\mathrm{FeO}$ & $2.52\}$ & 8.84 & $\{3.50\}$ & 8.24 & 2.82 & 3.07 & $3.59\}$ & 11.31 & 5.08 & 5.08 & 4.28 \\
\hline $\mathrm{MnO}$ & 0.131 & - & 0.062 & - & 0.113 & 0.094 & 0.099 & 0.143 & 0.036 & 0.113 & 0.084 \\
\hline $\mathrm{MgO}$ & 17.03 & - & 20.93 & - & 17.43 & 10.74 & 16.78 & 11.04 & 16.21 & 10.12 & 11.02 \\
\hline $\mathrm{CaO}$ & 4.67 & - & 2.93 & - & 10.11 & 3.75 & 2.74 & 10.39 & 3.35 & 9.81 & 5.79 \\
\hline $\mathrm{Na}_{2} \mathrm{O}$ & 1.39 & - & 1.08 & 1.15 & 0.94 & 3.61 & 1.47 & 1.83 & 1.26 & 2.35 & 1.66 \\
\hline $\mathrm{K}_{2} \mathrm{O}$ & 0.29 & - & 0.13 & - & 0.08 & 0.49 & 0.40 & 0.07 & 0.06 & 0.07 & 0.25 \\
\hline $\mathrm{P}_{2} \mathrm{O}$ & 0.066 & - & 0.045 & - & 0.045 & 0.064 & 0.060 & 0.068 & 0.059 & 0.116 & 0.077 \\
\hline Cs (ppm) & - & 1.7 & - & - & 0.5 & 1.7 & 2.6 & - & 0.8 & - & - \\
\hline Co & 36 & 39 & 2.6 & 19 & 7.5 & 27 & 16 & 30 & 6 & 25 & 30 \\
\hline V & 140 & - & - & - & - & 250 & - & 220 & - & 260 & 370 \\
\hline $\mathrm{Cr}$ & 275 & 381 & 24 & 212 & 100 & 292 & 136 & - & 48 & 184 & 273 \\
\hline $\mathrm{Zn}$ & 87 & - & 21 & - & 17 & 58 & - & - & - & 22 & - \\
\hline $\mathrm{Cd}$ & 0.05 & - & 0.10 & - & - & 0.29 & - & - & - & - & - \\
\hline $\mathrm{Sb}$ & 0.5 & - & 0.3 & - & 0.6 & 1.4 & 1.6 & - & 1.1 & 1.1 & - \\
\hline $\mathrm{Sc}$ & 35 & 47 & 2.4 & 21 & 8.4 & 38 & 18 & 30 & 6 & 27 & 43 \\
\hline La & 1.05 & 1.07 & 0.60 & 1.29 & 0.54 & 1.2 & 1.04 & - & 0.92 & 1.03 & 1.12 \\
\hline $\mathrm{Ce}$ & 3.61 & 6.3 & 2.9 & 5.7 & - & 6.6 & - & - & 3.6 & 8.1 & - \\
\hline $\mathrm{Sm}$ & 1.53 & 1.985 & 0.94 & 1.243 & 0.60 & 1.47 & 1.063 & 1.13 & 0.82 & 1.949 & 2.12 \\
\hline Eu & 0.558 & 0.601 & 0.259 & 0.640 & 0.208 & 0.661 & 0.258 & - & 0.195 & 1.014 & 0.774 \\
\hline $\mathrm{Tb}$ & 0.537 & - & - & 0.360 & 0.183 & 0.572 & 0.269 & - & 0.186 & 0.582 & 0.610 \\
\hline $\mathrm{Tm}$ & - & - & 0.111 & 0.343 & & 0.457 & 0.202 & - & 0.170 & - & - \\
\hline $\mathrm{Yb}$ & 1.650 & - & 0.662 & 1.301 & 0.559 & 2.490 & 1.305 & - & 0.750 & 2.020 & 2.130 \\
\hline Lu & 0.282 & 0.310 & 0.099 & 0.265 & 0.095 & 0.362 & 0.286 & - & 0.157 & 0.381 & 0.404 \\
\hline Hf & - & 2.3 & - & - & - & 1.4 & - & - & - & 1.6 & - \\
\hline Th & 2.3 & - & - & - & 0.7 & - & - & - & - & 0.9 & - \\
\hline $\mathrm{Au}$ & - & 0.168 & 0.775 & 0.015 & - & - & - & - & - & - & 0.164 \\
\hline Ag & - & 0.130 & - & 0.045 & - & 0.064 & - & - & - & - & - \\
\hline $\mathrm{Ta}$ & - & 0.2 & 0.2 & 0.3 & 0.2 & 0.1 & 0.7 & - & - & - & - \\
\hline
\end{tabular}

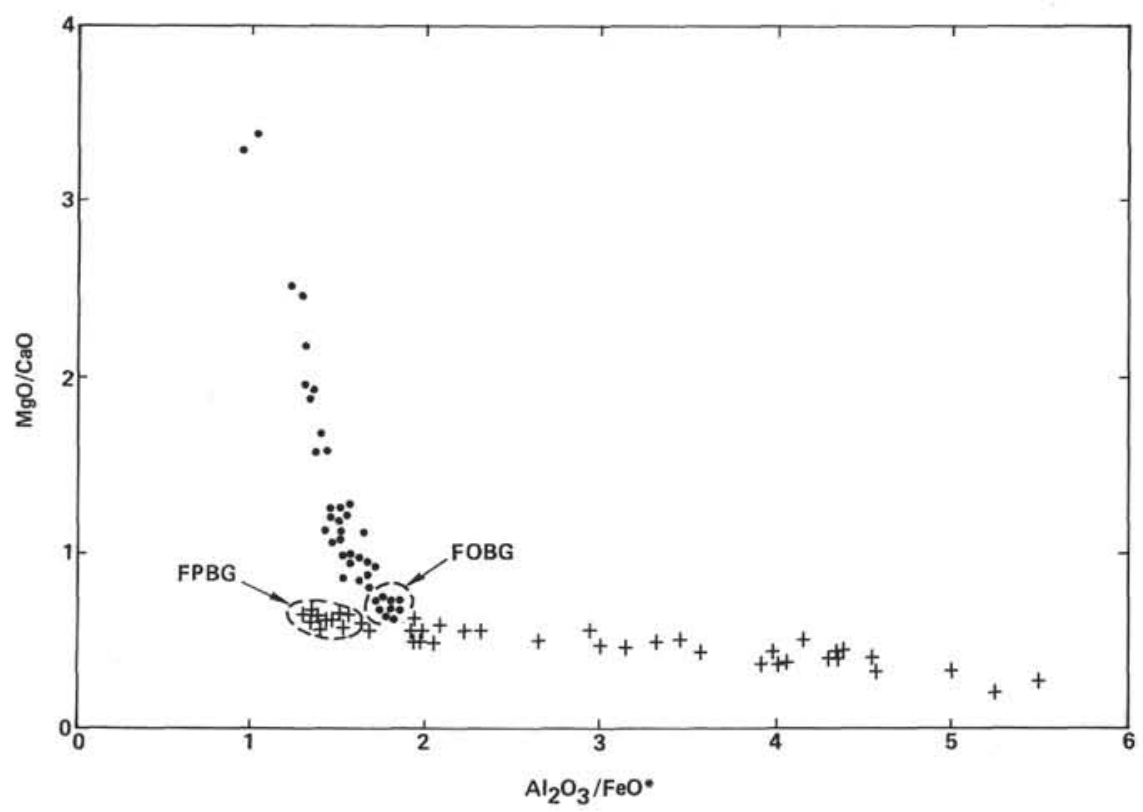

Figure 2. Two different OFT series on the $\mathrm{MgO} / \mathrm{CaO}$ versus $\mathrm{Al}_{2} \mathrm{O}_{3} / \mathrm{FeO} *$ correlation diagram. Dots = olivine phyric units from the Hole 332B (FAMOUS area, Mid-Atlantic Ridge) section; crosses = plagioclase phyric units from the same section. FPBG and FOBG = fields of plagioclase- and olivine-phyric basalt glasses. Data from Aumento, Melson, et al. (1977).

of secondary rock alterations (REE, Ta, Hf, Sc), also show regular distribution patterns, indicating their concentration rise along the differentiation trend (Fig. 4). Some other elements (such as Co and $\mathrm{Zn}$ ) have similar characteristics.
The cogenetic relation of studied rocks (including basalts from Holes 507 and 510) again is evidenced by the REE distribution patterns, which are nearly identical, having in all cases the LREE-depleted patterns (Figs. 5 and 6). At the same time, the observed regular decrease 

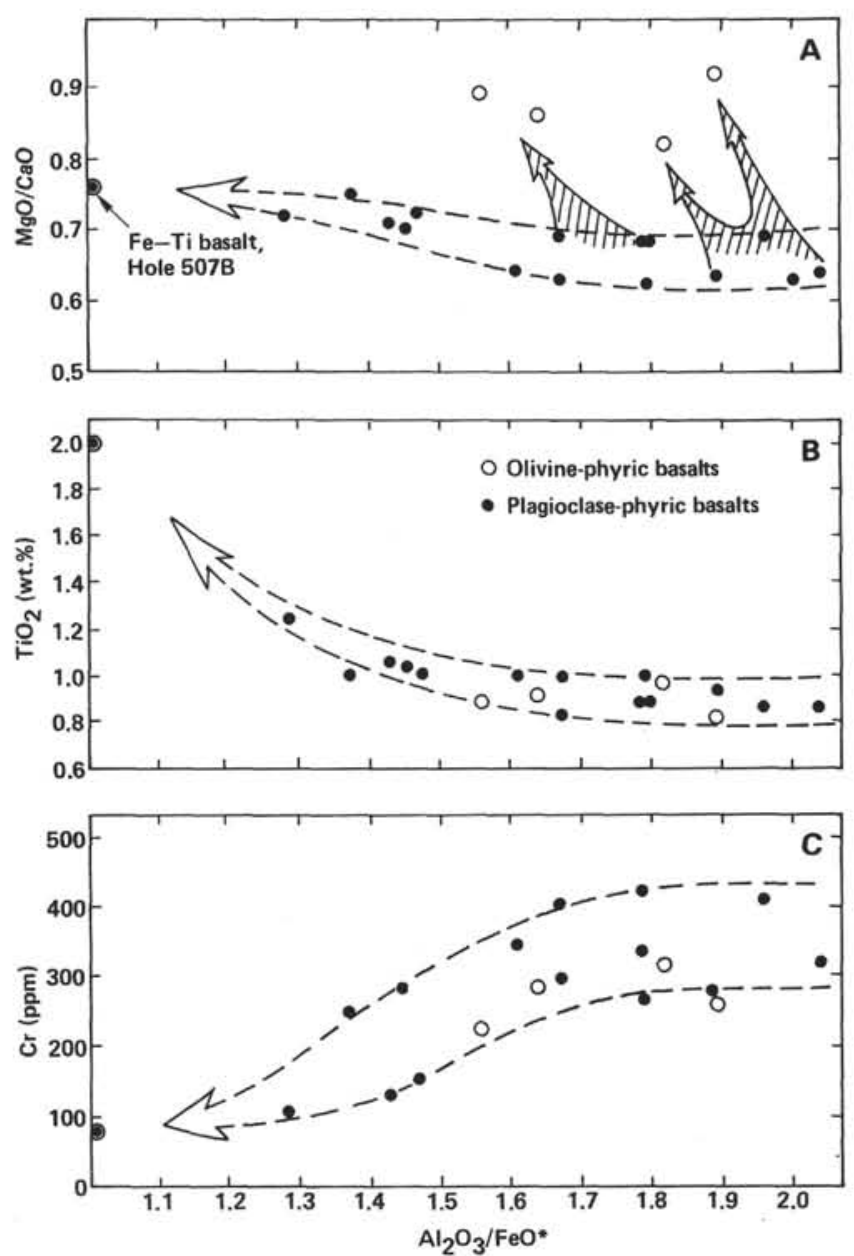

Figure 3. Inferred differentiation trends for the studied rock samples from the lower part of the Hole 504B (see text for explanation). Shaded arrows point to the olivine-enriched rocks. (A) $\mathrm{MgO} / \mathrm{CaO}$ vs. $\mathrm{Al}_{2} \mathrm{O}_{3} / \mathrm{FeO}^{*}$. (B) $\mathrm{TiO}_{2}$ vs. $\mathrm{Al}_{2} \mathrm{O}_{3} / \mathrm{FeO}^{*}$. (C) $\mathrm{Cr}$ vs. $\mathrm{Al}_{2} \mathrm{O}_{3} / \mathrm{FeO}^{*}$.

of the $\mathrm{Eu} / \mathrm{Sm}$ ratios (Fig. 7) parallel to diminishing $\mathrm{Al}_{2} \mathrm{O}_{3} / \mathrm{FeO}^{*}$ values points to the leading role of plagioclase in magma-fractionation.

As noted earlier, the shipboard scientific party has recognized the petrographic similarity of basalts from the upper and lower parts of the basement section recovered in Hole 504B. Figure 8 illustrates that both parts seem to be similar in chemical composition as well. Geochemical data obtained by the Leg 69 shipboard scientific party (Etoubleau et al., this volume) do not contradict this suggestion. Summarizing all the facts, we can speculate that the magmatic activity at this area of the Costa Rica Rift was of steady-state character, producing voluminous lava suites rather monotonous in composition.

\section{SECONDARY ALTERATION}

A number of publications (Hart, 1969; Miyashiro et al., 1969; Hart, 1970, 1973; Scott and Hajash, 1976; Bass, 1973, 1976; Honnorez et al., 1979, etc.) present data on the very important role of the halmyrolysis in the alteration of the ocean crust. This low-temperature process generally results in an increase of $\mathrm{H}_{2} \mathrm{O}^{+}, \mathrm{H}_{2} \mathrm{O}^{-}$, and $\mathrm{K}_{2} \mathrm{O}$ concentrations and $\mathrm{Fe}_{2} \mathrm{O}_{3} / \mathrm{FeO}$ ratios, because of the high oxidation ability of the sea water. At the same time, these and some other papers (e.g., Böhlke et al., 1980) evidence a gradual transition between the halmyrolysis and genuinely hydrothermal and metamorphic processes. For example, many secondary minerals (calcite, Fe-Mn-hydroxides, smectite, zeolites, etc.) are nearly identical in composition whether formed by lowtemperature reactions or by hydrothermal circulation at temperatures as high as $150^{\circ} \mathrm{C}$.

The thermal gradient in Hole 504B was studied both during Legs 69 and 70 . According to the results reported in this volume, the estimated temperature at the deepest point of the Hole ( $562 \mathrm{~m}$ beneath the basement) is about $120^{\circ} \mathrm{C}$ (Becker et al., this volume). With the kind assistance of Dr. V. B. Naumov, we determined the homogenization temperature of the fluid inclusions in analcime, separated from a vein (Sample 37-1, 96-99 cm; $550 \mathrm{~m}$ below the sea floor). The obtained value of $42 \pm 2{ }^{\circ} \mathrm{C}$, corrected to the pressure conditions gives a temperature for that interval of about $75^{\circ} \mathrm{C}$. This is in a good agreement with the estimated temperature for this depth based on temperature measurements in the hole. Consequently, secondary-mineral formation within the basalts of Hole 504B took place at temperatures of 75 to $120^{\circ} \mathrm{C}$.

Some of the analyzed rock samples contain more than $2 \% \mathrm{H}_{2} \mathrm{O}$ (Table 3), considerably more than fresh OFT. The $\mathrm{H}_{2} \mathrm{O}^{+}$concentrations in the Hole 504B samples correlate positively with the $\mathrm{Fe}_{2} \mathrm{O}_{3} / \mathrm{FeO}$ ratios and $\mathrm{K}_{2} \mathrm{O}$ contents (Figs. 9 and 10 ), as noted in the cited publications. There is also a positive correlation between $\mathrm{Fe}_{2} \mathrm{O}_{3}$ and the $\mathrm{K}_{2} \mathrm{O}$ contents (Fig. 11A), and all three indicators gain the highest values in the strongly smectitized rock zones and in smectites (Table 5).

The observed degree of rock alteration to a certain extent depends on the rock mineral composition. As noted previously, some of the samples are enriched in olivine compared with their counterparts from the same lithologic units. These rocks turn out to be the most altered by secondary processes. This is illustrated by the higher $\mathrm{K}_{2} \mathrm{O}$ concentration in these rocks relative to other petrographic types of basalts (Fig. 11B), and by general increases of $\mathrm{H}_{2} \mathrm{O}^{+}$and $\mathrm{K}_{2} \mathrm{O}$ contents, paralleling the higher $\mathrm{MgO}$ values (Fig. 12).

The increasing $\mathrm{K}_{2} \mathrm{O}$ contents and $\mathrm{Fe}_{2} \mathrm{O}_{3} / \mathrm{FeO}$ values in the rocks is accompanied by their enrichment in some other trace elements (e.g., lithium; Figs. 13 and 14). This element, like potassium, is more concentrated in olivine-rich rocks than in other rock types, because this element substitutes for its isomorph $\mathrm{Mg}$. Lithium behavior during rock oxidation is rather complicated.

According to the brief scientific report on the Legs 69 and 70 drilling results in the Costa Rica Rift (CRRUST, in press), the basalts of the upper part of the Hole 504B are more oxidized than rocks deeper in the hole. They contain abundant $\mathrm{Fe}$-hydroxides, and very rare sulfides, whereas in rocks from the lower part of the hole the proportions of these minerals are the opposite. Belyi et al. (this volume) suggest that there is a higher degree of rock oxidation in the upper part of the cored basalts, on 

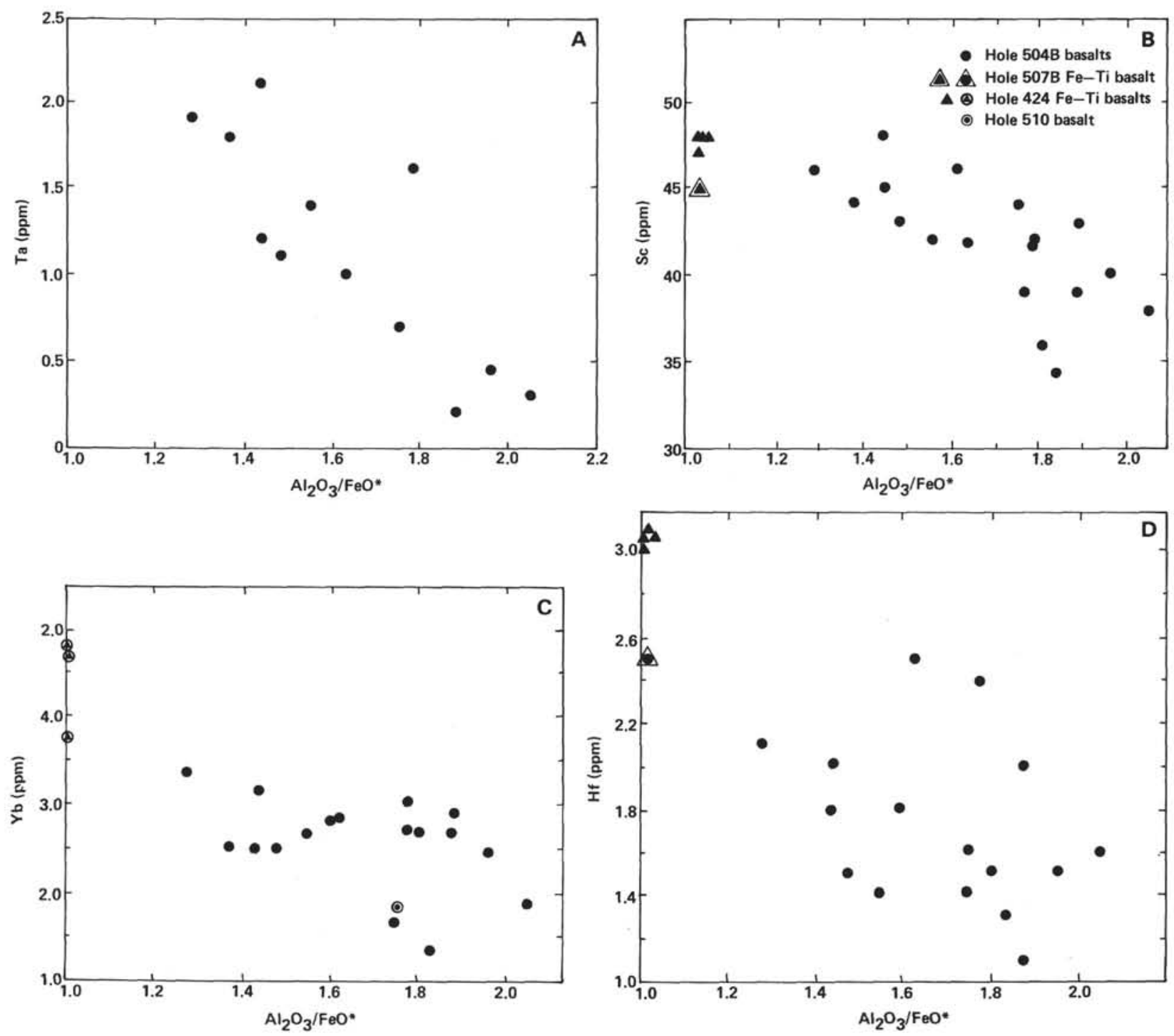

Figure 4. Correlation between some trace-element concentrations and $\mathrm{Al}_{2} \mathrm{O}_{3} / \mathrm{FeO}^{*}$ values in the $\mathrm{Hole} 504 \mathrm{~B}$ basalts.

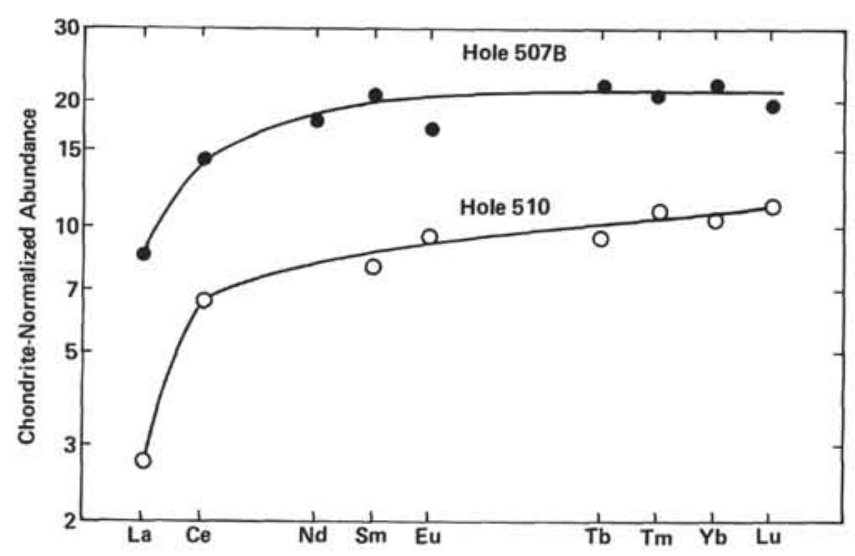

Figure 5. Chondrite-normalized REE patterns for Hole 507B and Hole 510 basalts. the basis of the distribution of sulfur and its isotopes. They find the primitive $\delta \mathrm{S}^{34}$ values deep in the hole. Barrett and Friedrichsen (this volume) found that sea water had influenced the strontium- and oxygen-isotope compositions of the basalts only in the upper part of the section. All these data indicate that sea water circulating through the basement rocks gradually loses its oxidation ability and may suffer changes in the concentrations of certain elements. Apparently, one such element is lithium. Its concentration in basalts from the lower part of the hole correlates positively with $\mathrm{Fe}_{2} \mathrm{O}_{3} / \mathrm{FeO}$ values up to $800 \mathrm{~m}$ sub-bottom. In the lowest parts of the basalt section that were drilled on Leg 70 (samples 1538-1564) there is no correlation between $\mathrm{Li}$ and $\mathrm{Fe}_{2} \mathrm{O}_{3} / \mathrm{FeO}$ (Fig. 14). Similarly, the low $\mathrm{K}_{2} \mathrm{O}$ contents in smectites from the lower part of the hole may reflect a gradual depletion of sea water in this component on its way down to the deeper basement horizons.

According to the logging results, there are several zones in Hole 504B which are highly permeable to sea 
water (Cann and Von Herzen, this volume). Rock-alteration phenomena in these zones may be traced by more detailed sampling. Some aspects of this problem are considered by Belyi et al. (this volume) in terms of the distribution of sulfur and its isotopes. Their data also indicate that rocks from such zones are characterized by higher $\mathrm{H}_{2} \mathrm{O}^{+}, \mathrm{K}_{2} \mathrm{O}$, and $\mathrm{Li}$ contents and higher $\mathrm{Fe}_{2} \mathrm{O}_{3}$ / $\mathrm{FeO}$ ratios than the rocks immediately above or below (see Figs. 3 and 4 in Belyi et al., this volume).

In addition to the rock chemical composition, we have analyzed several clay-mineral aggregates separated from veins or altered zones in the basalts. The diffractograms obtained for these samples show that they are smectites or mixed-layer clay minerals (chemical data and sample descriptions are given in Tables 5 and 6). Considering both chemistry and X-ray diffraction data, one must admit the heterogeneous nature of all samples. Several of them may even incorporate admixtures of rock material, which is evidenced by high concentrations of $\mathrm{CaO}$.

In spite of the sample heterogeneity, we can outline a general picture of element migration due to development of secondary minerals in veins and elsewhere.

Normalizing the chemical composition of the studied clay aggregates to the wall-rock compositions (Fig. 15), we can see that they are deficient in $\mathrm{Na}_{2} \mathrm{O}, \mathrm{CaO}$, and $\mathrm{Fe}^{2+}$, but enriched in $\mathrm{MgO}, \mathrm{K}_{2} \mathrm{O}$, and $\mathrm{Fe}^{3+}$. It is also evident that smectites from the lower part of the Hole (samples 1122-1304; Table 5) contain more total iron than smectite of the saponitic type from the upper horizons. This may be related to the higher $\mathrm{Ti}$ and $\mathrm{Fe}$ concentrations in the host basalts.

The observed REE patterns in the clay aggregates (Fig. 16) have a strong similarity to the patterns of these elements in the basalts, but their bulk concentrations are significantly lower (Fig. 17). A single unusual REE spectrum with the strong heavy REE enrichment (up to 1.5 times higher than in the host basalts) was observed only in sample 224 (Fig. 17). It may indicate a more intensive mobilization of the heavy REE in the course of secondary alteration.

Compared with host basalts, the secondary clay aggregates are depleted in $\mathrm{Cr}, \mathrm{Sc}$, and $\mathrm{Co}$; at the same time, some of these aggregates contain remarkably high $\mathrm{Zn}, \mathrm{Au}$, and $\mathrm{Ag}$ concentrations (Table 5). These facts enable us to suggest that all these elements were redistributed by hydrothermal processes.

In addition to the clay aggregates, we were able to separate and analyze only a few analcime and pyrite samples (Table 7). There are extremely low concentrations of trace elements in analcime, which has a REE spectrum different from that of the other secondary minerals. That is, it has features strongly reflecting seawater characteristics, rather than the compositions of host basalts.

\section{CONCLUDING REMARKS}

The available data on the deep-penetration DSDP holes indicate the variable intensity of volcanic activity along the oceanic spreading center. For example, volcanic eruptions at the FAMOUS area were intermittent, being separated by notable periods of the pelagic sedimentations (Aumento, Melson, et al., 1977). The diversity in lava compositions, characteristic of this area, is believed to be caused by several factors: (1) by differences in primary melt compositions, (2) by intensive differentiation in shallow magma chambers, (3) by mixing of the variably evolved magmas before eruption.

The comparable (in thickness) basaltic sequence in the area of the Mid-Atlantic Ridge near $23^{\circ} \mathrm{N}$ (Holes 395 and 396) consists of lavas which are rather monotonous in composition. They differ geochemically from the FAMOUS basalts, but here, too, there were long periods between eruptions (Melson, Rabinowitz, et al., 1979; Dmitriev, Heirtzler, et al., 1979).

A third example of the deep hole in the mid-oceanridge crustal area is Hole 504B. The DSDP Legs 69 and 70 results together with these data enable us to emphasize the following peculiarities of basaltic basement in this area of the eastern Pacific:

1) Massive lava flows, up to 2.3 meters thick, are more characteristic of the Costa Rica Rift than other drilled ridges. They are especially abundant in the lower part of the section (Site 504 report, this volume).

2) Neither coring nor logging results indicate the presence of a significant sedimentary layer within the penetrated basaltic section.

3) The obtained geochemical data suggest the cogenetic nature of the recovered volcanic series, consisting of rocks with compositional variations produced by restrained plagioclase (and sometimes olivine) fractionation under low-pressure conditions. These peculiarities testify to the high intensity and the steady-state character of magmatic activity during formation of the Costa Rica Rift structure, resulting in voluminous eruptions of poorly evolved lavas. This may be related to higher spreading rates on the Costa Rica Rift than on the MidAtlantic Ridge.

The Galapagos spreading center, which includes the Costa Rica Rift, is an area of intensive present-day hydrothermal activity. The observed secondary alteration of the Hole 504B basement rocks is in many aspects similar to those produced by rock and sea-water interaction at low temperatures (e.g., Site 396, Mid-Atlantic Ridge; Honnorez et al., 1979; Böhlke et al., 1980). However, the development of Fe-hydroxides, calcites, and K-rich clay minerals (nearly celadonites) occurs only in the upper 300 meters of the drilled basement section. Deeper, there are dominantly smectites of the saponite type, sometimes with high $\mathrm{Fe}$ content, and the degree of sulfide mineralization increases.

There is a positive correlation among the samples between the $\mathrm{Fe}$ oxidation state and the $\mathrm{H}_{2} \mathrm{O}^{+}, \mathrm{K}_{2} \mathrm{O}$, and $\mathrm{Li}$ concentrations, indicating that sea water was the agent of rock alteration. The observed regularities in mineralogical and geochemical changes of the alteration products suggest that sea water infiltrating the basement rocks gradually loses its oxidation ability and such components as $\mathrm{K}, \mathrm{Li}$, and $\mathrm{CO}_{2}$. The evolution of the circulating-water composition is also evidenced by the strontium-, oxygen-, and sulfur-isotope data obtained by Barrett and Friedrichsen and Belyi et al. (both this vol- 

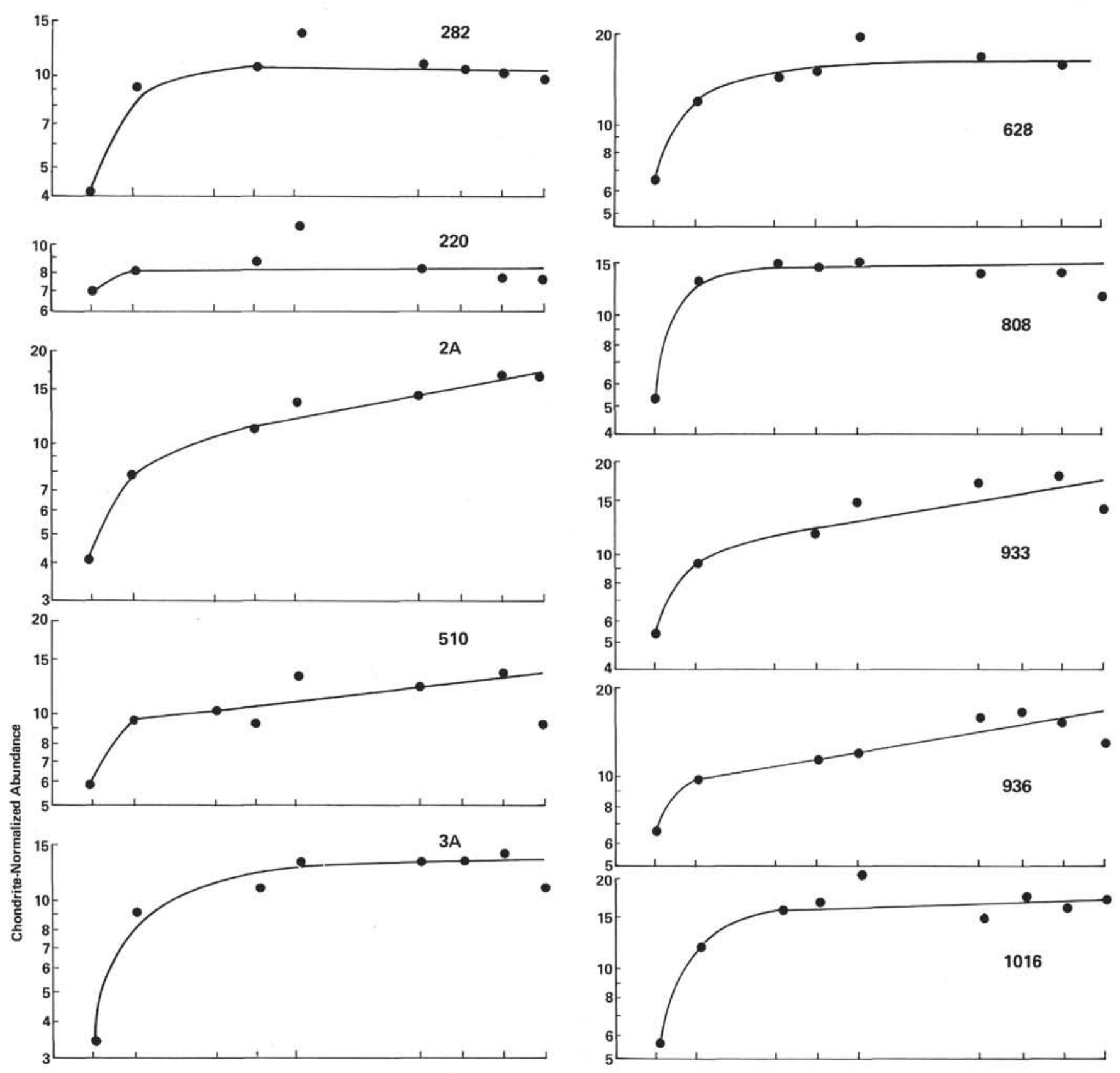

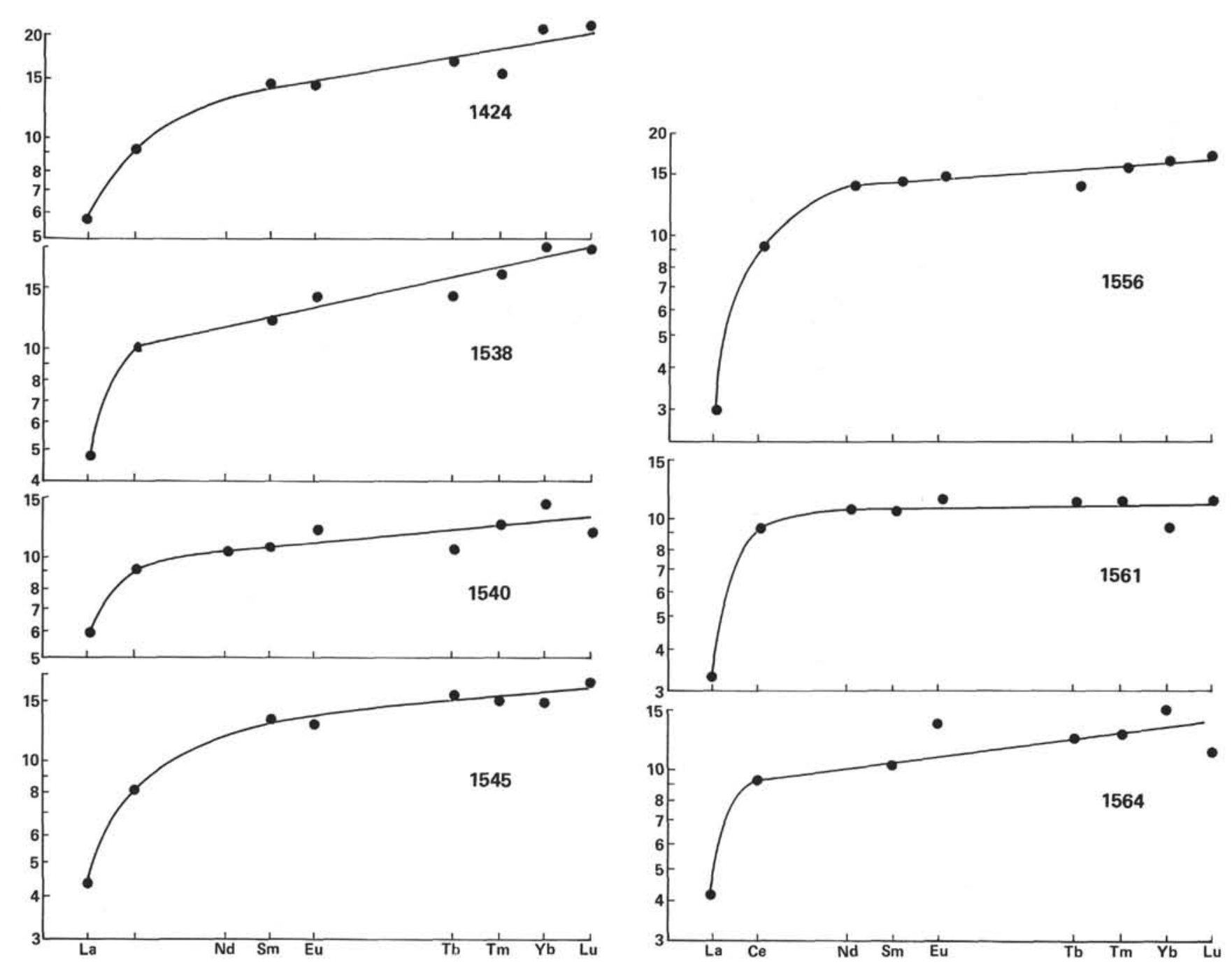

Figure 6. Chondrite-normalized REE patterns for Hole 504B basalts. 


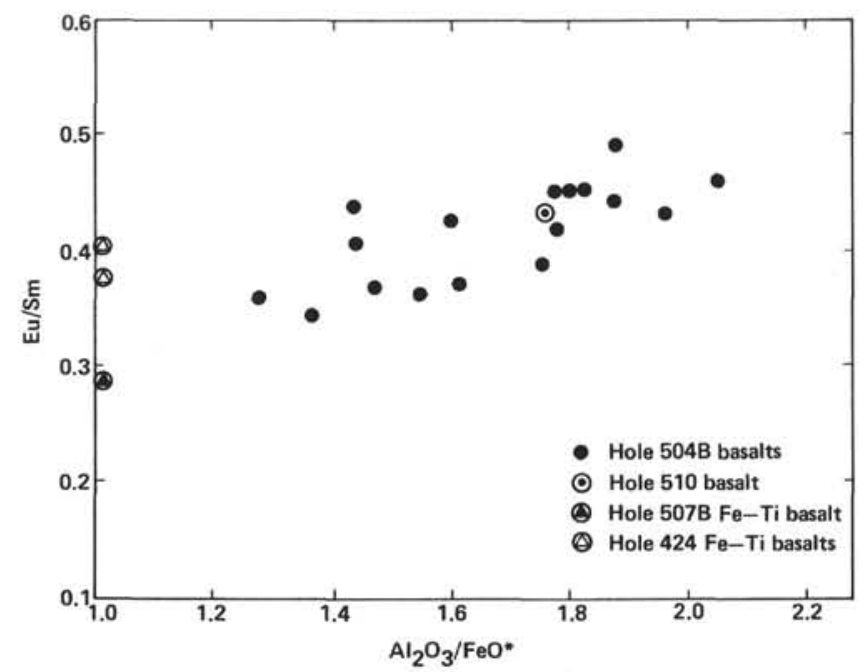

Figure 7. Eu/Sm versus $\mathrm{Al}_{2} \mathrm{O}_{3} / \mathrm{FeO}^{*}$ correlation diagram for Hole 504B basalts.

ume). The REE distribution patterns of the secondary clay aggregates generally are similar to those of host basalts, but have the elevated La concentrations compared with heavier REE, and sometimes have higher $\mathrm{Yb}$ and Lu values. These modifications of the REE spectra are clearly expressed in smectites from the upper horizons (samples 224 and 282), where analcime with a sea-water REE pattern was found. The influence of sea water on the REE distribution is less evident in the middle part of the section (samples 510, 517, 777 and 779), and nearly absent deep in the Hole (samples 1122 and 1304). The general depletion of the secondary clay minerals in $\mathrm{REE}, \mathrm{Cr}, \mathrm{Sc}, \mathrm{Co}, \mathrm{Zn}$, etc. relative to the primary rocks is accompanied in some cases by $\mathrm{Ag}, \mathrm{Au}$, and heavyREE enrichment, but only in the upper part of the section (samples 242, 282, 401-1). All these tendencies in element redistributions are based on a limited amount of data and certainly need to be verified by more-comprehensive study.

\section{REFERENCES}

Aumento F., Melson W. G., et al., 1977. Init. Repts. DSDP, 37: Washington (U.S. Govt. Printing Office).

Bass M. N., 1976. Secondary minerals in oceanic basalt, with special reference to Leg 34, Deep Sea Drilling Project. In Yeats, R. S., Hart, S. R., et al., Init. Repts. DSDP, 34: Washington (U.S. Govt. Printing Office), 393-432.

Bass, M. N., Moberly, R., Rhodes J. M., Shih, C., and Church, S. E., 1973. Volcanic rocks cored in the Central Pacific, Leg 17, Deep Sea Drilling Project. In Winterer, E. L., Ewing, J. I., et al., Init. Repts. DSDP, 17: Washington (U.S. Govt. Printing Office), 429-503.

Böhlke, J. K., Honnorez, J., and Honnorez-Guerstein, B.-M., 1980. Alteration of basalts from Site 396B, DSDP: petrographic and mineralogic studies. Contrib. Mineral. Petrol., 73:341-364.
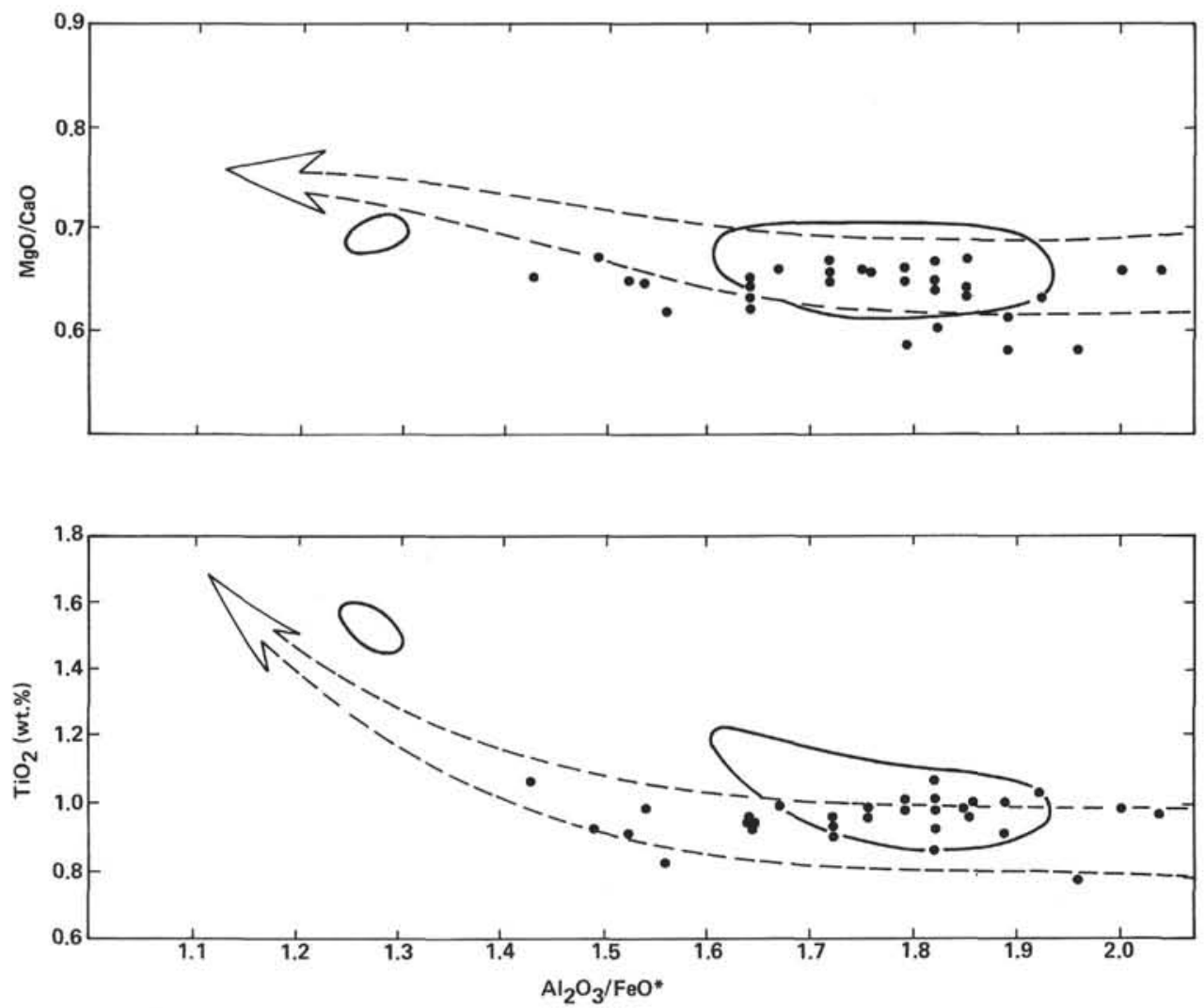

Figure 8. Compositional variations in the Hole 504B basalts. Dots represent rocks from the upper part of the hole (data from Etoubleau et al., this volume); arrows as in Figure 3; solid line contour represents basalt-glass compositions from the Galapagos spreading center (data from Melson et al., 1977). 
CRRUST, in press. Geothermal regimes of the Costa Rica Rift, East Pacific, investigated by drilling, DSDP-IPOD Legs 68, 69 and 70. Geol. Soc. Am. Bull.

Dmitriev, L., Heirtzler, J., et al., 1979. Init. Repts. DSDP, 46: Washington (U.S. Govt. Printing Office).

Flanagan, F. J., 1973. 1972 values for international geochemical reference samples. Geochim. Cosmochim. Acta, 37:1189-1200.

Hart, R., 1970. Chemical exchange between sea water and deep ocean basalts. Earth Planet. Sci. Lett., 9:269-279.

Hart, R. A., 1973. A model for chemical exchange in the basalt-seawater system of Oceanic Layer II. Canadian J. Earth Sci., 10: 799-816.

Hart, S. R., 1969. K, Rb, Cs contents and K/Rb, K/Cs ratios of fresh and altered submarine basalts. Earth Planet. Sci. Lett., 6:295-303.

Honnorez, J., Böhlke, J. K., and Honnorez-Guerstein, B. M., 1979. Petrographical and geochemical study of the low temperature sub-

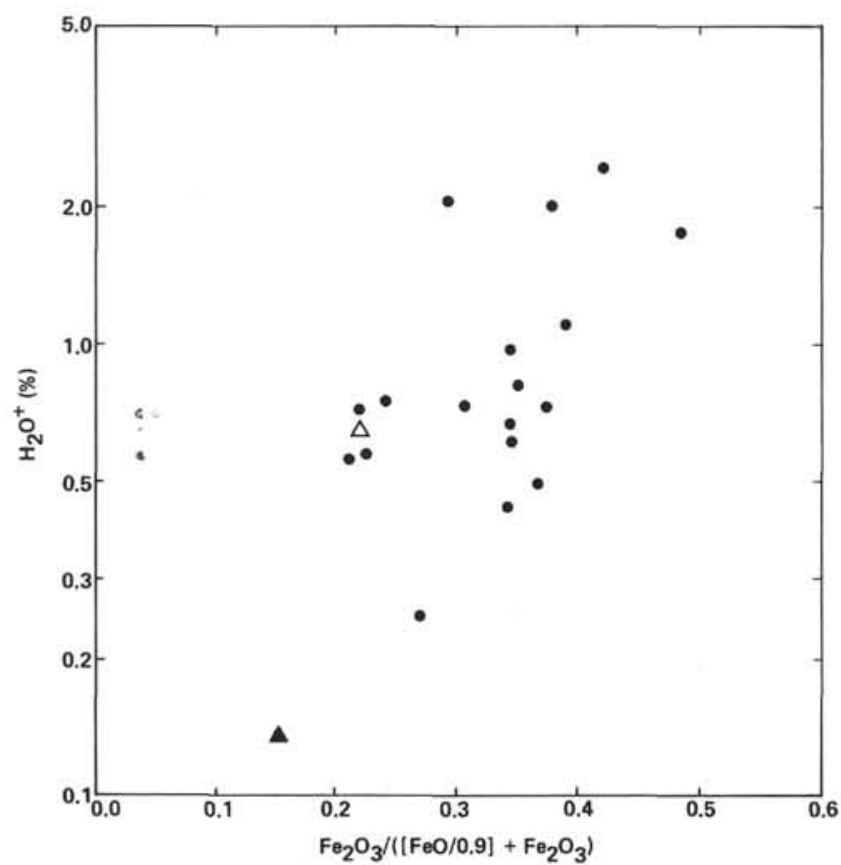

Figure 9. $\mathrm{H}_{2} \mathrm{O}^{+}$versus $\mathrm{Fe}_{2} \mathrm{O}_{3} /\left([\mathrm{FeO} / 0.9]+\mathrm{Fe}_{2} \mathrm{O}_{3}\right)$ correlation diagram for the studied rock samples. Dots represent Hole 504B rocks; solid triangle represents Hole 507B sample; open triangle represents Hole 510 sample. marine alteration of basalt from Hole 396B, Leg 46. In Dmitriev, L., Heirtzler, J., et al., Init. Repts. DSDP, 46: Washington (U.S. Govt. Printing Office), 299-329.

Melson, W. G., Byerly, G. R., Nelen, J. A., O'Hearn, T., Wright, T. L., and Vallier, T., 1977. A catalog of the major element chemistry of abyssal volcanic glasses. Smithsonian Contrib. to the Earth Sci., 19: Washington (Smithsonian Inst. Press), 31-60.

Melson, W. G., Rabinowitz, P. D., et al., 1979. Init. Repts. DSDP, 45: Washington (U.S. Govt. Printing Office).

Migdisov, A. A., Girin, Yu. P., Galimov, E. M., Grinenko, V. A., Barskaya, N. V., Krivitsky, V. A., Sobornov, O. P., and Cherkovsky, S. L., 1979. Major and minor elements and sulfur isotopes of the Mesozoic and Cenozoic sediments at Sites 415 and 416, Leg 50, Deep Sea Drilling Project. In Lancelot, Y., Winterer, E. L., et al., Init. Repts. DSDP, 50: Washington (U.S. Govt. Printing Office), 675-689.

Migdisov, A. A., Miklishansky, A. Z., Saveliev, B. V., Bredanova, N. V., Girin, Yu. P., Pavlutskaya, V. I., and Yakovlev, Y. V., 1981. Neutron activation analysis of rare earth elements and some other trace elements in volcanic ashes and pelagic clays, Deep Sea Drilling Project Leg 59. In Kroenke, L., Scott, R., et al., Init. Repts. DSDP, 59: Washington (U.S. Govt. Printing Office), 653-668.

Miyashiro, A., Shido, F., and Ewing, M., 1969. Diversity and origin of abyssal tholeiite from the Mid-Atlantic Ridge near $24^{\circ}$ and $30^{\circ}$ North latitude. Contrib. Mineral. Petrol., 23:38-52.

Scott, R. B., and Hajash, A., Jr., 1976. Initial submarine alteration of basaltic pillow lavas: a microprobe study. Amer. J. Sci., 276: 480-501.

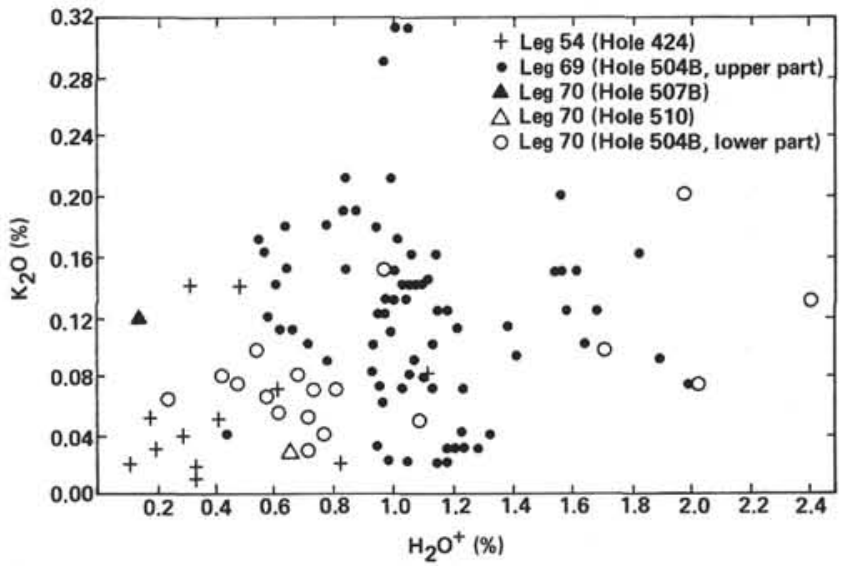

Figure $10 . \mathrm{K}_{2} \mathrm{O}$ versus $\mathrm{H}_{2} \mathrm{O}^{+}$correlation diagram. 

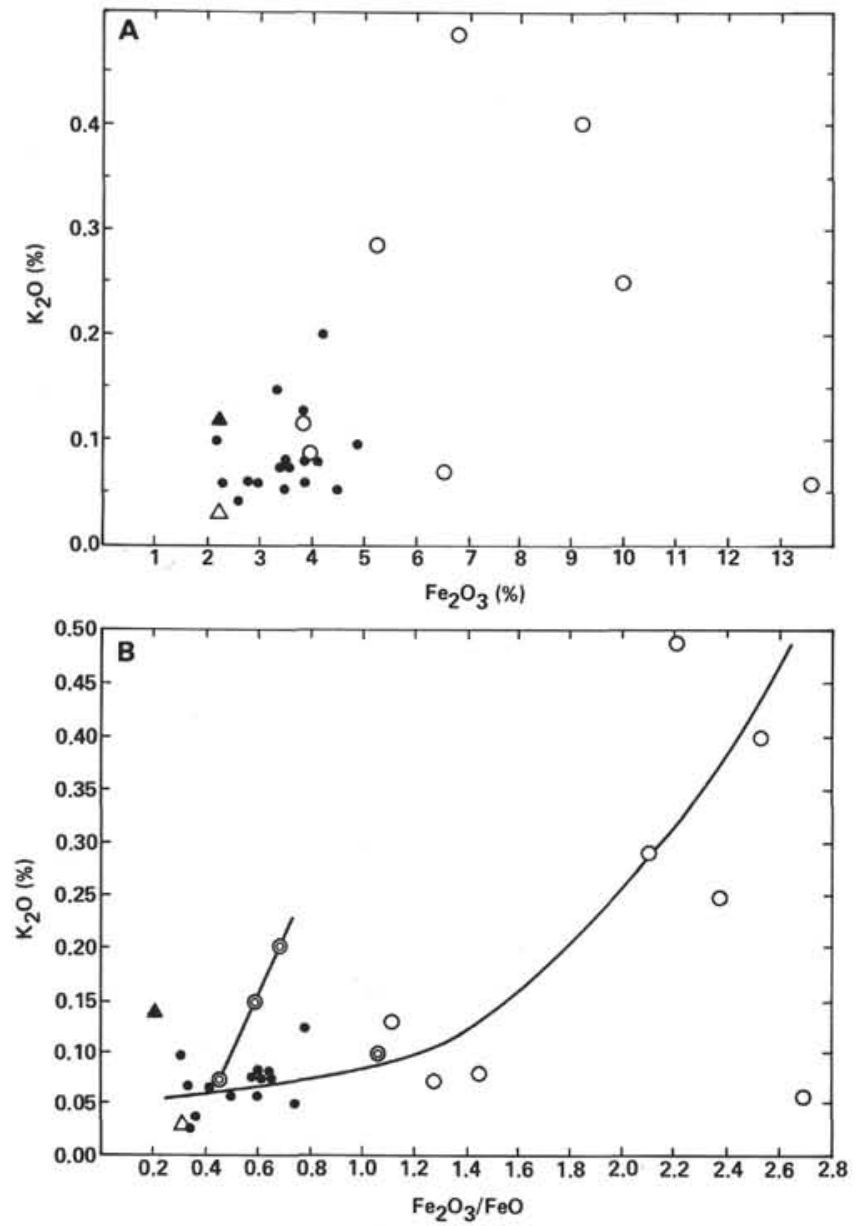

Figure 11. $\mathrm{K}_{2} \mathrm{O}$ versus $\mathrm{Fe}_{2} \mathrm{O}_{3}(\mathrm{~A})$ and $\mathrm{K}_{2} \mathrm{O}$ versus $\mathrm{Fe}_{2} \mathrm{O}_{3} / \mathrm{FeO}$ (B) correlation diagrams for the studied rocks and their alteration products. Open circles represent alteration products (smectites) from the Hole 504B basalts; double circles represent Ol-rich basalts; other symbols as in Figure 9. Curved line is hand drawn to show that the general trend of basalt alteration is dominated by formation of smectites. Olivine-rich basalts (linked by short, steep line) do not conform to this pattern of alteration.
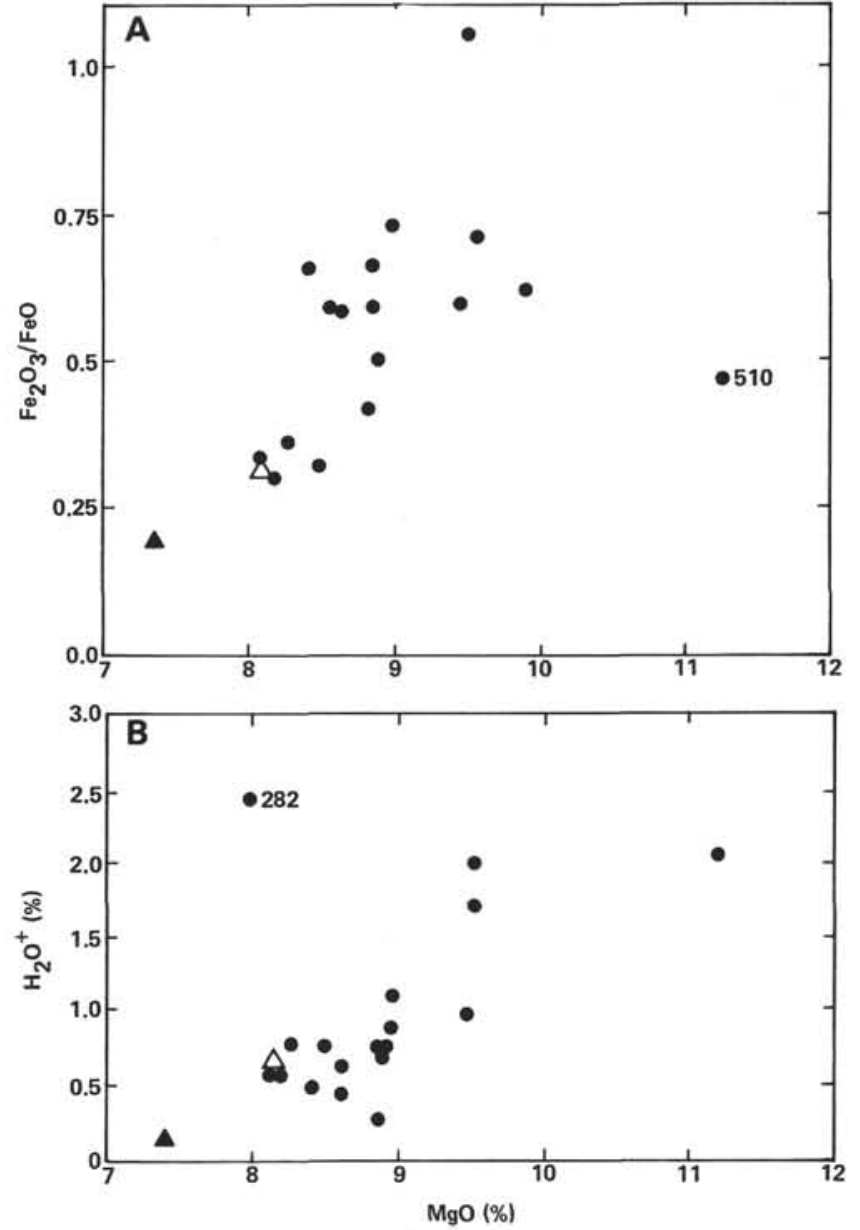

Figure 12. $\mathrm{MgO}$ versus $\mathrm{Fe}_{2} \mathrm{O}_{3} / \mathrm{FeO}$ (A) and $\mathrm{MgO}$ versus $\mathrm{H}_{2} \mathrm{O}^{+}$(B) correlation diagrams for the studied rock samples. Symbols as in Figure 9.

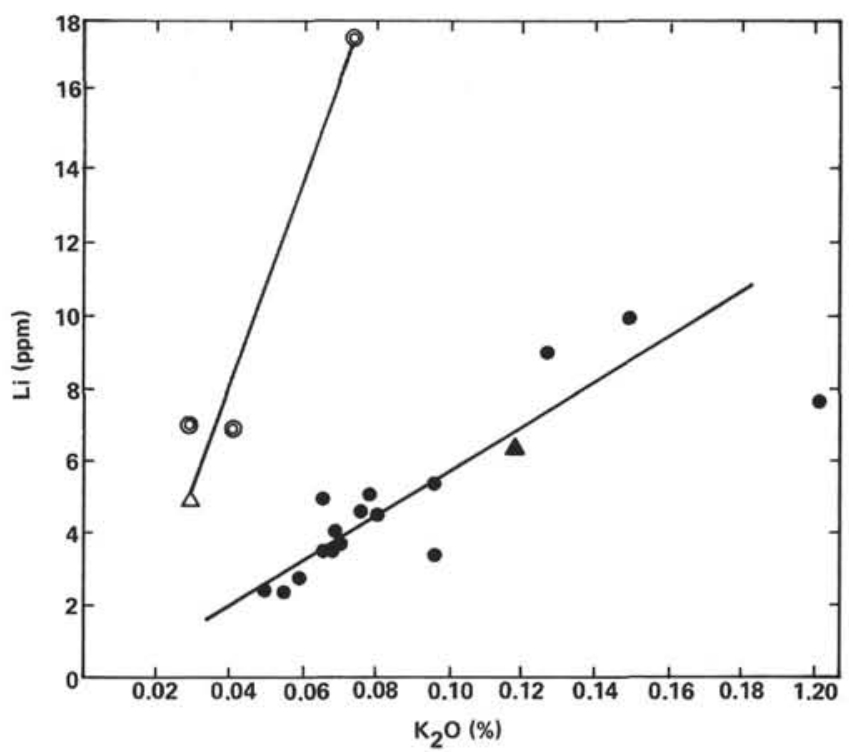

Figure 13. $\mathrm{Li}$ versus $\mathrm{K}_{2} \mathrm{O}$ correlation diagram for the studied rock samples. Symbols as in Figure 11. Lines are hand drawn through olivine-rich basalts (steeper line) and all other basalts (flatter line). 


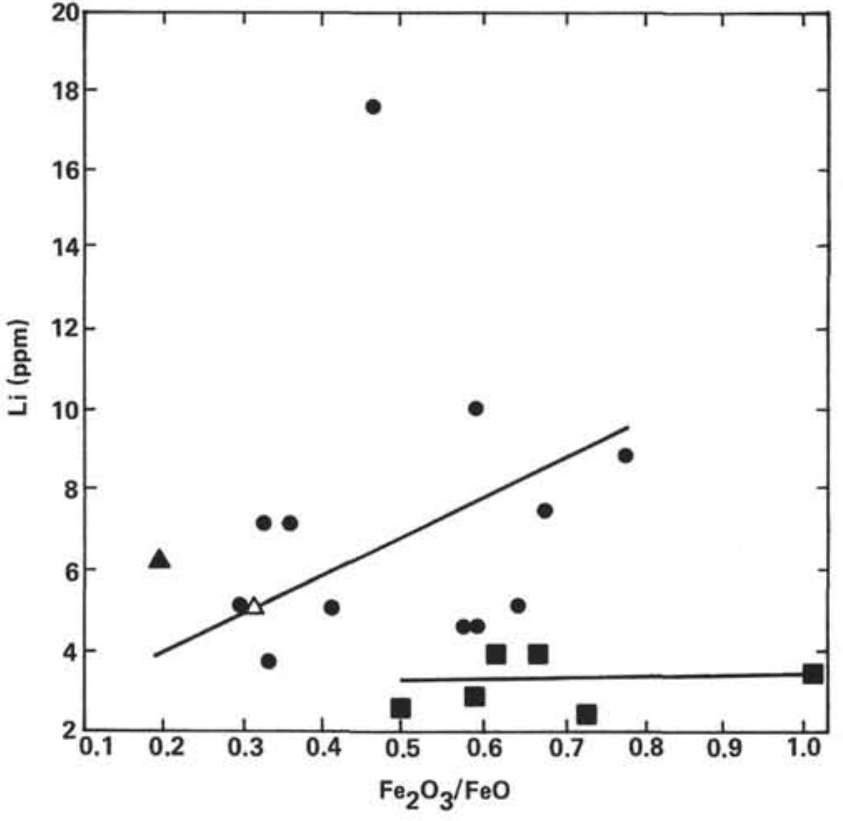

Figure 14. $\mathrm{Li}$ versus $\mathrm{Fe}_{2} \mathrm{O}_{3} / \mathrm{FeO}$ correlation diagram for the studied rock samples. Upper line is hand drawn through data for samples from upper oxidized portion of basement (symbols as in Fig. 9, except that dots represent rocks from upper part of Hole 504B only [Cores 34-64]). The lower line is drawn through data (solid squares) for samples from the lower (unoxidized) portion of basement in Hole 504B (Cores 68-70).
Table 6. Minerals and their aggregates from alteration zones and veins in Hole 504B basalts.

\begin{tabular}{|c|c|c|c|}
\hline Piece No. & Sample No. & $\begin{array}{c}\text { Sample } \\
\text { (interval in } \mathrm{cm} \text { ) }\end{array}$ & Sample Description \\
\hline 224 & 161 & $504 \mathrm{~B}-31-1,47-50$ & $\begin{array}{l}\text { Olive-green smectite from vein in altered basalt } \\
\text { in association with zeolite and carbonate }\end{array}$ \\
\hline 282 & 151 & 504B-35-1, 14-18 & $\begin{array}{l}\text { Transparent pale-rose analcime from vein in } \\
\text { altered basalt }\end{array}$ \\
\hline 282 & 149 & $504 \mathrm{~B}-35-1,14-18$ & $\begin{array}{l}\text { The same, with inclusions of Fe-hydroxide } \\
\text { globules }\end{array}$ \\
\hline 282 & 157 & 504B-35-1, 14-18 & $\begin{array}{l}\text { Grayish-green smectite from vein in association } \\
\text { with analcime and carbonate }\end{array}$ \\
\hline $401-1$ & - & $504 \mathrm{~B}-37-3,70-75$ & Olive-green smectite from vein in basalt \\
\hline 510 & 154 & $504 \mathrm{~B}-40-1,55-60$ & $\begin{array}{l}\text { Dark-green smectite from alteration zone in } \\
\text { basalt }\end{array}$ \\
\hline 517 & - & $504 \mathrm{~B}-40-1,90-95$ & Green smectite from vein \\
\hline 777 & - & $504 \mathrm{~B}-46-1,100-105$ & $\begin{array}{l}\text { Olive-green mineral from alteration zone in } \\
\text { basalt }\end{array}$ \\
\hline 779 & - & $504 \mathrm{~B}-46-1,100-105$ & $\begin{array}{l}\text { Dark-green poor crystallized mineral from thick } \\
\text { vein }\end{array}$ \\
\hline 852 & 153 & $504 \mathrm{~B}-47-4,23-32$ & Pyrite from smectite vein \\
\hline 1000 & 148 & 504B-52-1, $82-87$ & $\begin{array}{l}\text { Grayish-green aggregate of clay minerals from } \\
\text { vein }\end{array}$ \\
\hline 1122 & 151 & $504 \mathrm{~B}-56-2,98-103$ & $\begin{array}{l}\text { Dark-green mineral as a film on basalt frag- } \\
\text { ments }\end{array}$ \\
\hline 1164 & 147 & $504 \mathrm{~B}-57-3,31-43$ & Dark olive-green smeetite from vein with pyrite \\
\hline 1226 & - & 504B-58-3, 10-15 & $\begin{array}{l}\text { Large aggregate of well-crystallized pyrite in } \\
\text { fracture filled with smectite }\end{array}$ \\
\hline 1304 & - & $504 \mathrm{~B}-61-2,67-70$ & Dark-olive-green smectite on basalt \\
\hline 1460 & - & $504 \mathrm{~B}-64-4,10-12$ & Pyrite in smectite vein \\
\hline
\end{tabular}

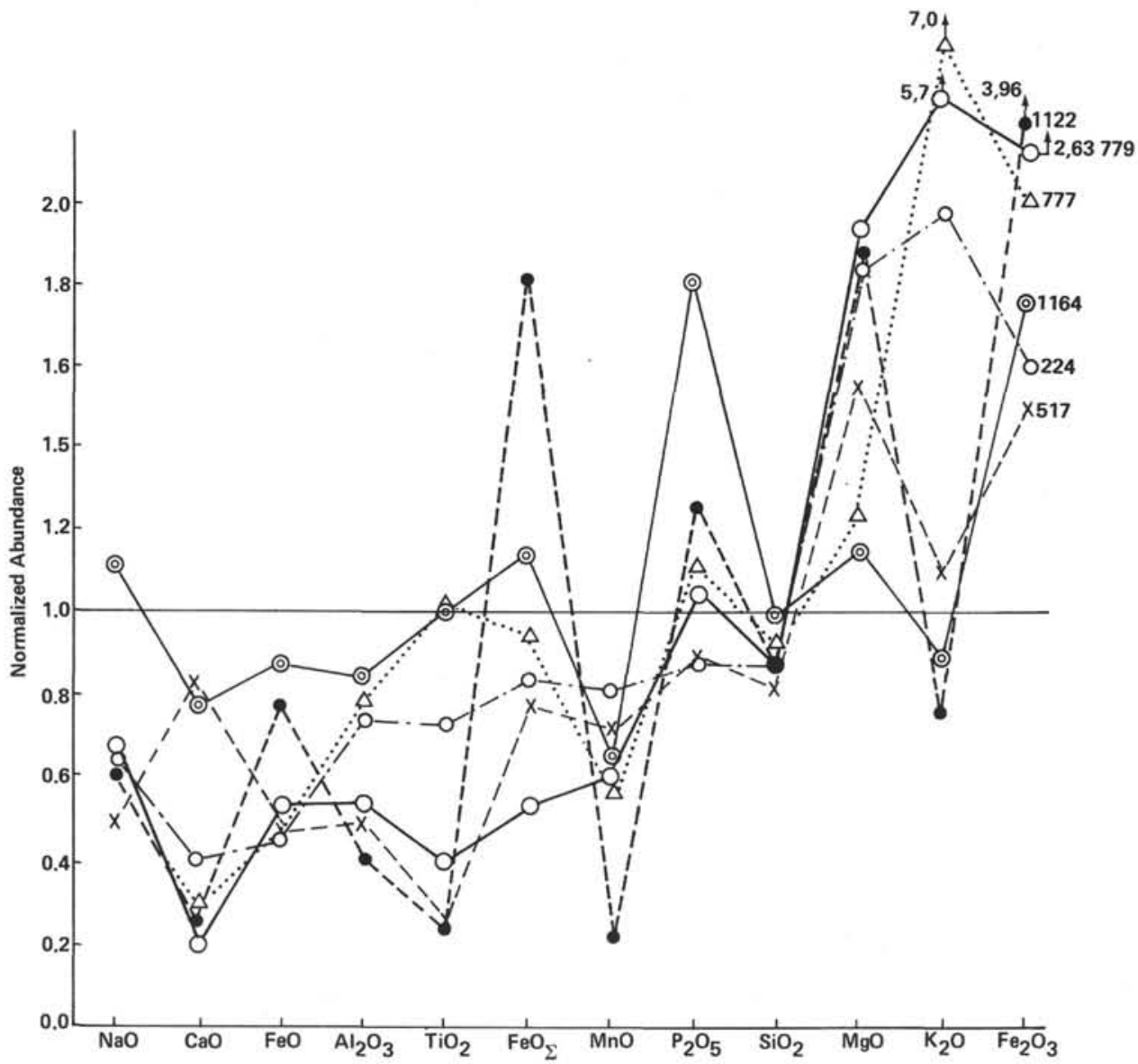

Figure 15. Major-element composition of the alteration products normalized to the host basalt compositions (number of samples as in Table 5). 
A. YA. SHARASKIN, A. A. MIGDISOV, I. A. ROSTSCHINA, A. Z. MIKLISHANSKY

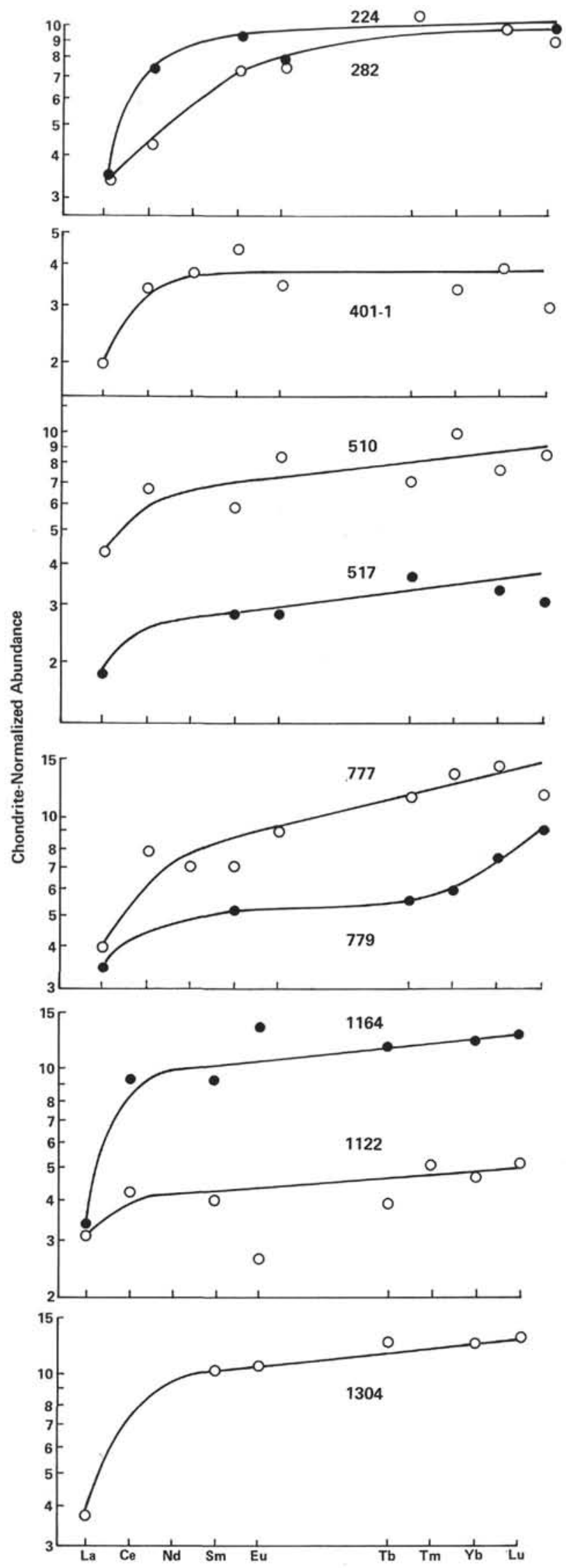

Figure 16. Chondrite-normalized REE patterns in the Hole 504B alteration products. 


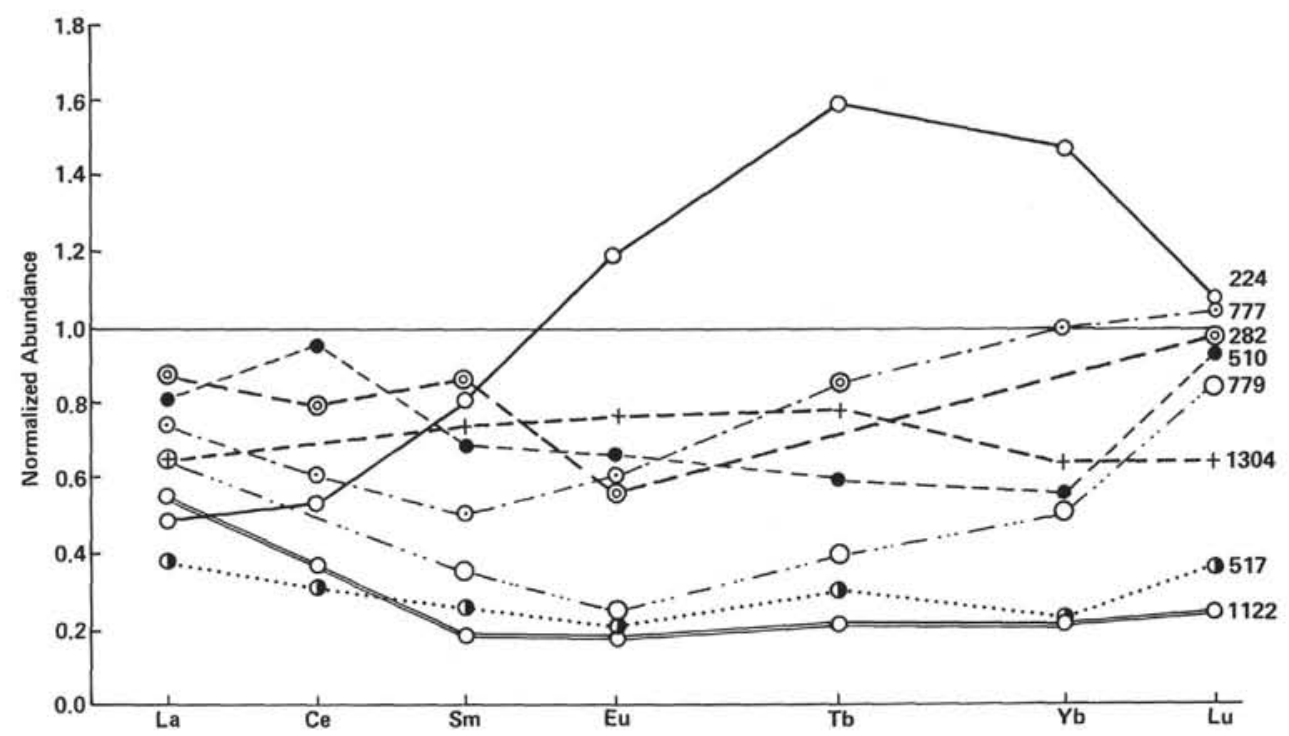

Figure 17. REE distributions in the alteration products normalized to the REE concentrations of the host basalts.

Table 7. Analyses of analcimes and pyrites from veins in Hole 504B basalts.

\begin{tabular}{|c|c|c|c|c|c|}
\hline Component & $\begin{array}{l}\text { Analcime, } \\
\text { No. } 155\end{array}$ & $\begin{array}{l}\text { Analcime with Globules } \\
\text { of Goethite, } \\
\text { No. } 149\end{array}$ & $\begin{array}{l}\text { Pyrite, } \\
\text { No. } 852\end{array}$ & $\begin{array}{c}\text { Pyrite, } \\
\text { No. } 1226\end{array}$ & $\begin{array}{l}\text { Pyrite with a Touch } \\
\text { of Smectite, } \\
\text { No. } 1460\end{array}$ \\
\hline $\begin{array}{l}\mathrm{Fe}_{2} \mathrm{O}_{3}(\%) \\
\mathrm{Na}_{2} \mathrm{O}\end{array}$ & $\begin{array}{r}0.07 \\
13.95\end{array}$ & $\begin{array}{r}1.95 \\
12.35\end{array}$ & 52.8 & 65.8 & 30.3 \\
\hline $\mathrm{Pb}(\mathrm{ppm})$ & 6.6 & $\begin{array}{c}12.35 \\
-\end{array}$ & - & - & - \\
\hline Cs & 1.1 & 1.0 & 2.0 & $=$ & $=$ \\
\hline Co & $i$ & 2.8 & 20 & 23 & 20 \\
\hline $\mathrm{Cr}$ & 1.7 & - & 46 & - & 87 \\
\hline $\mathrm{Zn}$ & 2.7 & - & 40 & - & - \\
\hline $\mathrm{Cd}$ & 0.02 & - & 0.47 & - & - \\
\hline $\mathrm{Sb}$ & - & - & 2.7 & - & - \\
\hline Se & 0.2 & 0.5 & 9.0 & 1.3 & 20 \\
\hline La & 0.5 & 2.6 & 1.9 & 0.5 & - \\
\hline $\mathrm{Ce}$ & 0.5 & - & - & - & - \\
\hline $\mathrm{Sm}$ & 0.24 & - & 0.7 & 0.24 & 0.67 \\
\hline Eu & - & $=$ & 0.364 & 0.061 & - \\
\hline $\mathrm{Tb}$ & 0.112 & - & - & 0.055 & - \\
\hline $\mathrm{Yb}$ & - & - & - & 0.252 & - \\
\hline Lu & - & $=$ & 0.160 & 0.036 & - \\
\hline
\end{tabular}

